\title{
THE SIZE AND QUALITY OF THE LAW SCHOOL APPLICANT POOL: 1982-1986 AND BEYOND
}

\author{
DAVID H. VERNON* \\ AND BRUCE I. ZIMMER**
}

Nationally, the size of the law school applicant pool has declined from 1982 to $1986,{ }^{1}$ and the academic credentials (combined undergraduate GPAs and LSAT scores) of those in the applicant pool have decreased at a faster rate than the size of the pool itself. ${ }^{2}$ This article $^{3}$ considers the educational tensions created by the different rates at which pool size, acadeinic credentials, and enrollment liave decreased over the five-year period. ${ }^{4}$ It goes on to analyze the potential future qualitative consequences of these trends. ${ }^{5}$ Finally, it offers a tentative forecast about the probable size and quality of the national applicant pool over the next few years. ${ }^{6}$

\section{The Applicant Pool from 1982 to 1986: The Statistics}

National quantitative data about legal education are presented as a

* Allan D. Vestal Professor of Law, University of Iowa College of Law. A.B., L.L.B., Harvard; L.L.M., J.S.D., New York University.

** Executive Vice President, Law School Admission Services and Executive Director, Law School Admission Council. A.B., Columbia; J.D., New York University.

Professor Vernon chaired a committee on demand for legal education appointed jointly by the Association of American Law Schools and the Law School Admission Council. The committee issued a report in 1980. See Association of AMERICAN LAW Schools \& LAW School Admis-

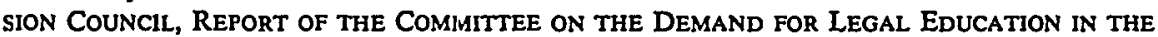
1980's (1980) [hereinafter REPORT ON DEMAND]. The report is available from the Office of the Executive Vice President, Law School Admission Services, P.O. Box 40, Newtown, Pa. 18940.

The authors acknowledge the extensive and valuable contributions of Dr. William J. Kennish, Consulting Systems Engineer, Law School Admission Services, to the organization, analysis, and presentation of much of the data in this article.

1. See infro notes 7-13 and accompanying text.

2. See infra notes 14-19 and accompanying text.

3. This article represents an extension of an earlier article. See Vernon \& Zimmer, The Demand for Legal Education: 1984 and the Future, 35 J. LEGAL EDUc. 261 (1985). In addition to updating the earlier article, this article analyzes the qualitative consequences of the declining law school applicant pool.

4. See infra notes $20-28$ and accompanying text.

5. See infra notes 35.43 and accompanying text.

6. See infra notes $44-46$ and accompanying text. 
starting point for analysis. ${ }^{7}$ Although national figures and trends tell us little about the conditions at any one school, they provide a common base from which to think about legal education in a macro sense, and they help individual schools determine where they stand in relation to other schools. ${ }^{8}$

As Table 1 shows, the number of law school applicants decreased $16.2 \%$ over the last five admission years. In 1986, however, there was a

Table 1

Applicant Pool - Classes Admitted From 1982 through 1986

\begin{tabular}{|lccccc|}
\hline & 1982 & 1983 & 1984 & 1985 & 1986 \\
Number of & 72,912 & 71,755 & 64,079 & 60,338 & 61,133 \\
Applicants & 100 & 98.4 & 87.9 & 82.7 & 83.8 \\
Index & & & & & \\
Number of & 307,476 & 301,268 & 266,802 & 252,538 & 251,299 \\
Applications & 100 & 98.0 & 86.8 & 82.1 & 81.7 \\
Index & & & & & \\
Applications & 4.22 & 4.20 & 4.16 & 4.19 & 4.11 \\
\hline Per Applicant & & & & & \\
\hline
\end{tabular}

slight $(1.1 \%)$ increase over the prior year. The increase may signal an end to dechining applicant pools; it may, however, simply mark an aberration in a continuing downward trend.

Some legal educators assume that a large majority of law school applicants apply for admission during their semor undergraduate year, ${ }^{9}$ and law school recruiting efforts have tended to focus on college se-

7. Except as otherwise specifically noted, data concerning the applicant pool (information about the number of applicants, the number of applications submitted by each applicant, the sex and race of applicants, and the academic credentials of those in the applicant pool (LSAT scores and undergraduate GPAs)) were provided by the Law School Admission Council/Law School Admission Services (LSAC/LSAS).

Data concerning the number of enrolled students are taken from the annual reviews of legal education published by the Section of Legal Education and Admissions to the Bar of the American Bar Association. See A Review of Legal Education in the United States: Fall 1985, 1986 A.B.A. SEC. LEGAL EDUC. \& ADMISSIONS TO B. [hereinafter 1985 REPORT]; A Review of Legal Education in the United States: Fall 1983, 1984 A.B.A. SEC. LEGAL EDUC. \& ADMISSIONS To B. [hereinafter 1983 REPORT]; A Review of Legal Education in the United States: Fall 1972, 1973 A.B.A. SEC. LEGAL EDUC. \& ADMissions TO B. [hereinafter 1972 REPORT]. The 1986 data are found in a February 5 , 1987 press release by James P. White, consultant to the Section of Legal Education and Admissions to the Bar.

8. The data presented in the article relate only to ABA-approved law schools.

9. See, eg., REPORT ON DEMAND, supra note **. The report focused its demographic analysis on 22-and 23-year-olds on the assumption that the applicant pool was overwhelmingly composed of graduating college seniors. 
niors. ${ }^{10}$ The assumption, however, has been inconsistent with the facts for several years. Table 2 shows that over the last five admission years, only 40 to $42 \%$ of those in the pool were college seniors. Furthermore, the number of college seniors in the pool decreased at a somewhat higher

Table 2

Undergraduate Degree Date of Persons in the Apphicant Pool: 1982-1986

\begin{tabular}{|c|c|c|c|c|c|c|c|c|c|c|}
\hline $\begin{array}{l}\text { Degree } \\
\text { Date }\end{array}$ & 1982 & $\begin{array}{l}\% \text { of } \\
\text { Pool }\end{array}$ & 1983 & $\begin{array}{l}\% \text { of } \\
\text { Pool }\end{array}$ & 1984 & $\begin{array}{l}\% \text { of } \\
\text { Pool }\end{array}$ & 1985 & $\begin{array}{l}\% \text { of } \\
\text { Pool }\end{array}$ & 1986 & $\begin{array}{l}\% \text { of } \\
\text { Pool }\end{array}$ \\
\hline $\begin{array}{l}\text { Senior } \\
+1 \text { yr. } \\
+2 \text { yr. } \\
+3 \text { yr. } \\
+4 \text { yr. } \\
\text { Total: }\end{array}$ & $\begin{array}{r}30,528 \\
10,556 \\
6,265 \\
4,301 \\
3,386 \\
55,046\end{array}$ & $\begin{array}{r}42 \\
14 \\
9 \\
6 \\
4 \\
75\end{array}$ & $\begin{array}{r}29,426 \\
10,728 \\
6,084 \\
4,192 \\
3,213 \\
53,643\end{array}$ & $\begin{array}{r}41 \\
15 \\
8 \\
6 \\
4 \\
75\end{array}$ & $\begin{array}{r}26,749 \\
9,129 \\
5,435 \\
3,690 \\
2,805 \\
47,808\end{array}$ & $\begin{array}{r}41 \\
14 \\
8 \\
6 \\
4 \\
75\end{array}$ & $\begin{array}{r}25,267 \\
8,229 \\
4,825 \\
3,421 \\
2,552 \\
44,294\end{array}$ & $\begin{array}{r}42 \\
14 \\
8 \\
6 \\
4 \\
73\end{array}$ & $\begin{array}{r}24,363 \\
8,595 \\
5,301 \\
3,668 \\
2,733 \\
44,660\end{array}$ & $\begin{array}{r}40 \\
14 \\
7 \\
6 \\
4 \\
73\end{array}$ \\
\hline $1-4$ yrs. & 24,518 & 33 & 24,217 & 34 & 21,059 & 34 & 19,027 & 31 & 20,297 & 33 \\
\hline $\begin{array}{l}5+\text { yrs. } \\
\& \text { Over } \\
\text { No Date }\end{array}$ & $\begin{array}{r}16,443 \\
1,423\end{array}$ & $\begin{array}{r}22 \\
2\end{array}$ & $\begin{array}{r}16,538 \\
1,574\end{array}$ & $\begin{array}{r}23 \\
2\end{array}$ & $\begin{array}{r}14,699 \\
1,572\end{array}$ & $\begin{array}{r}23 \\
2\end{array}$ & $\begin{array}{r}14,118 \\
1,926\end{array}$ & $\begin{array}{r}23 \\
3\end{array}$ & $\begin{array}{r}14,593 \\
1,880\end{array}$ & $\begin{array}{r}24 \\
3\end{array}$ \\
\hline
\end{tabular}

rate than the decrease in the overall pool- 6165 fewer seniors were in the pool in 1986 than in 1982, a decline of $20.2 \%$ as compared to a $16.2 \%$ decline in the size of the entire pool. Over the same five-year period, the number of applicants who had been out of school for one to four years fell $17.2 \%$, from 24,518 to 20,297 . By contrast, the number of applicants who earned degrees five or more years before they applied to law school fell only $11.2 \%$ during the same period, from 16,443 to 14,593 . The changing pattern can be seen in Figure I.

When analyzing the 1982-1985 decline in the law school applicant pool, one should note that 1984 was the year that the number of undergraduate degrees awarded peaked as well as the year that the law school applicant pool shrunk at the greatest rate. Table 3 shows that, from 1982 to 1986, a shrinking percentage of those earning baccalaureate degrees opted to apply to law school during their senior year, although the rate of decline has abated somewhat since 1984. ${ }^{11}$ The trend can be seen in Figure II. In commercial terms, law schools have been losing their share of the graduating-senior market over the past five years.

10. For the last three years, most law schools have participated in a series of Law School Forums (recruiting fairs) held in urban areas around the country and have had the opportunity for direct contact with two to three thousand potential applicants who were not then enrolled at a college or university. These events are sponsored and coordinated by the LSAC/LSAS.

11. See Table 3. 


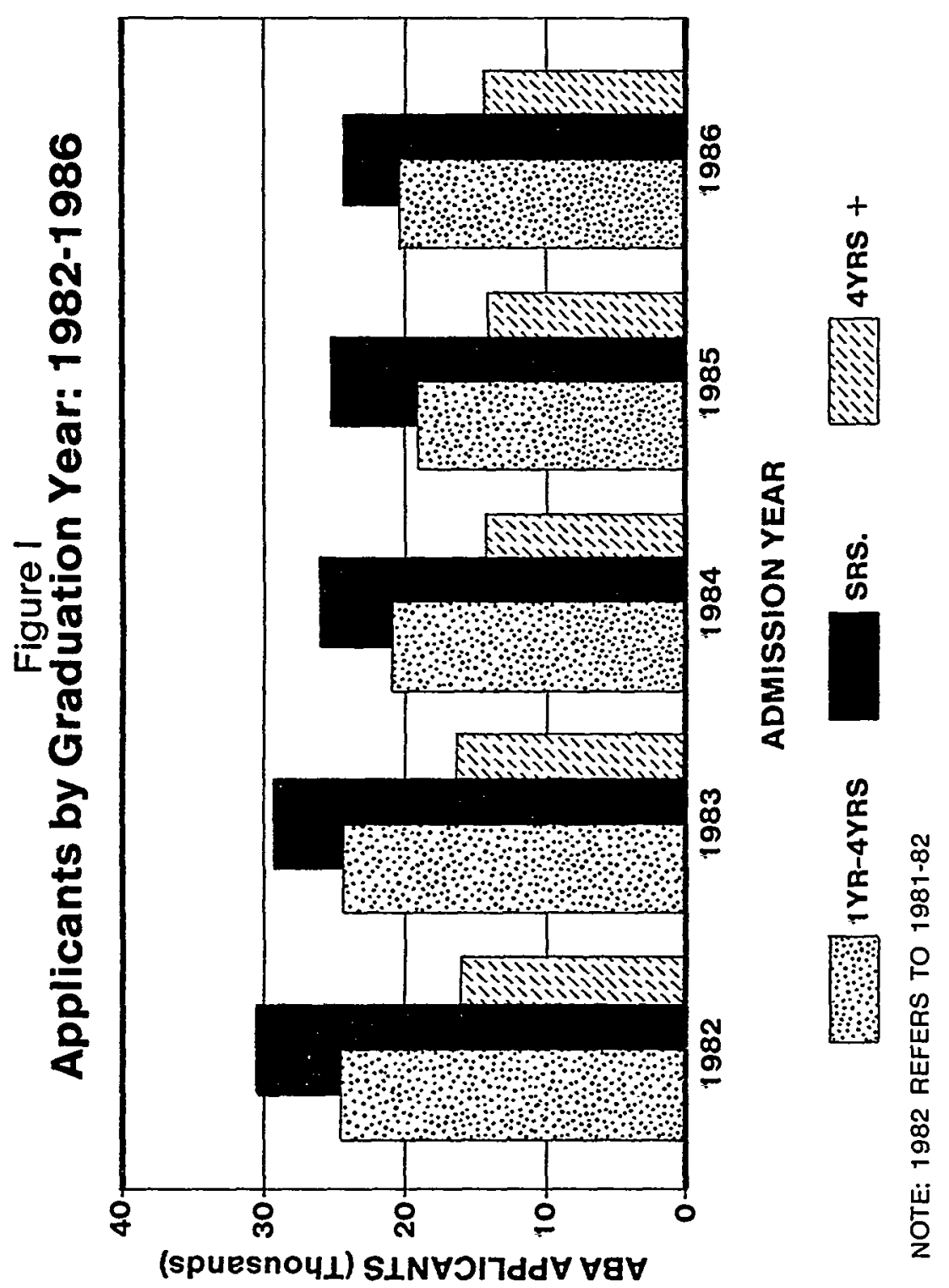




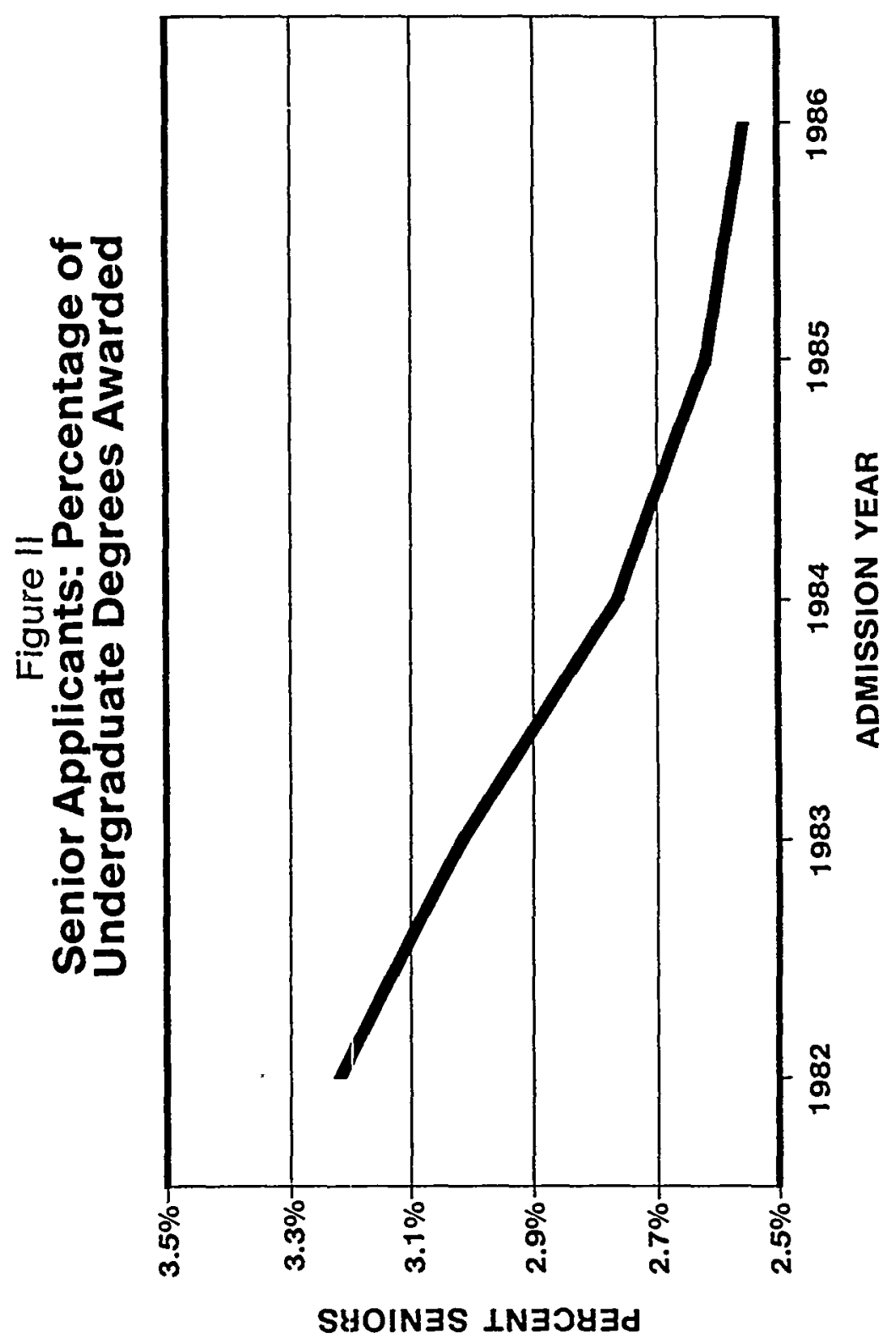


Table 3

Percentage of Graduating Seniors Applying Directly to Law School: 1982-1986

\begin{tabular}{|ccccc|}
\hline Year & $\begin{array}{c}\text { Undergraduate } \\
\text { Degrees Awarded }\end{array}$ & $\begin{array}{c}\text { Senior Applicants } \\
\text { to Law School }\end{array}$ & $\begin{array}{c}\text { \% of } \\
\text { Senior Pool }\end{array}$ & $\begin{array}{c}\text { \% Index } \\
(1982 \text { as Base) }\end{array}$ \\
1982 & 952,000 & 30,528 & 3.21 & 100 \\
1983 & 970,000 & 29,426 & 3.03 & 94 \\
1984 & 970,000 & 26,749 & 2.76 & 86 \\
1985 & 960,000 & 25,267 & 2.63 & 82 \\
1986 & 945,000 & 24,363 & 2.58 & 80 \\
\hline
\end{tabular}

The decline in the number of graduating-senior apphcants varied along regional and gender lines. Between 1982 and 1986, the number of senior applicants from the East and the West ${ }^{12}$ fell about $20 \%$, while the nuinber from the South fell only $14 \%$. The Midwest was the big loser, with a $27 \%$ decline in the number of senior applicants. During the same period, the number of male senior applicants fell at a faster rate than did the number of female senior applicants-24.5\% versus $13 \%$.

Despite the fact that the 1986 pool was $1.1 \%$ larger than the 1985 pool, there were, as shown in Table 3,3.6\% fewer senior applicants in 1986 than in 1985. Senior applicants were the only group whose numbers declined from 1985 to 1986 . Even in that single year, decreases varied along regional and gender lines. Between 1985 and 1986, the number of semor applicants from the Midwest fell by $9 \%$, while the number of Midwestern senior male applicants fell by about $12 \%$. Although the nuinber of Eastern seniors applying to law school decreased by only $4 \%$ between 1985 and 1986, there was a $7 \%$ drop in the

12. The regional definitions used throughout the article are as listed below and reflect the home addresses reported to ISAS by applicants.

\begin{tabular}{|c|c|c|c|}
\hline East & Midwest & South & West \\
\hline $\begin{array}{l}\text { Conn. } \\
\text { Del. } \\
\text { Me. } \\
\text { Md. } \\
\text { Mass. } \\
\text { N.H. } \\
\text { N.J. } \\
\text { N.Y. } \\
\text { Pa. } \\
\text { R.I. } \\
\text { Vt. } \\
\text { D.C. } \\
\text { P.R. } \\
\text { V.I. }\end{array}$ & $\begin{array}{l}\text { IIl. } \\
\text { Ind. } \\
\text { Iowa } \\
\text { Kan. } \\
\text { Mich. } \\
\text { Minn. } \\
\text { Mo. } \\
\text { Neb. } \\
\text { N.D. } \\
\text { Ohio } \\
\text { S.D. } \\
\text { Wis. }\end{array}$ & $\begin{array}{l}\text { Ala. } \\
\text { Ark. } \\
\text { Fla. } \\
\text { Ga. } \\
\text { Ky. } \\
\text { La. } \\
\text { Miss. } \\
\text { N.C. } \\
\text { S.C. } \\
\text { Tenn. } \\
\text { Va. } \\
\text { W.Va. } \\
\text { C.Z. }\end{array}$ & $\begin{array}{l}\text { Alaska } \\
\text { Ariz. } \\
\text { Cal. } \\
\text { Colo. } \\
\text { Haw. } \\
\text { Idaho } \\
\text { Mont. } \\
\text { Nev. } \\
\text { N.M. } \\
\text { Okla. } \\
\text { Or. } \\
\text { Tex. } \\
\text { Utah } \\
\text { Wash. } \\
\text { Guam }\end{array}$ \\
\hline
\end{tabular}




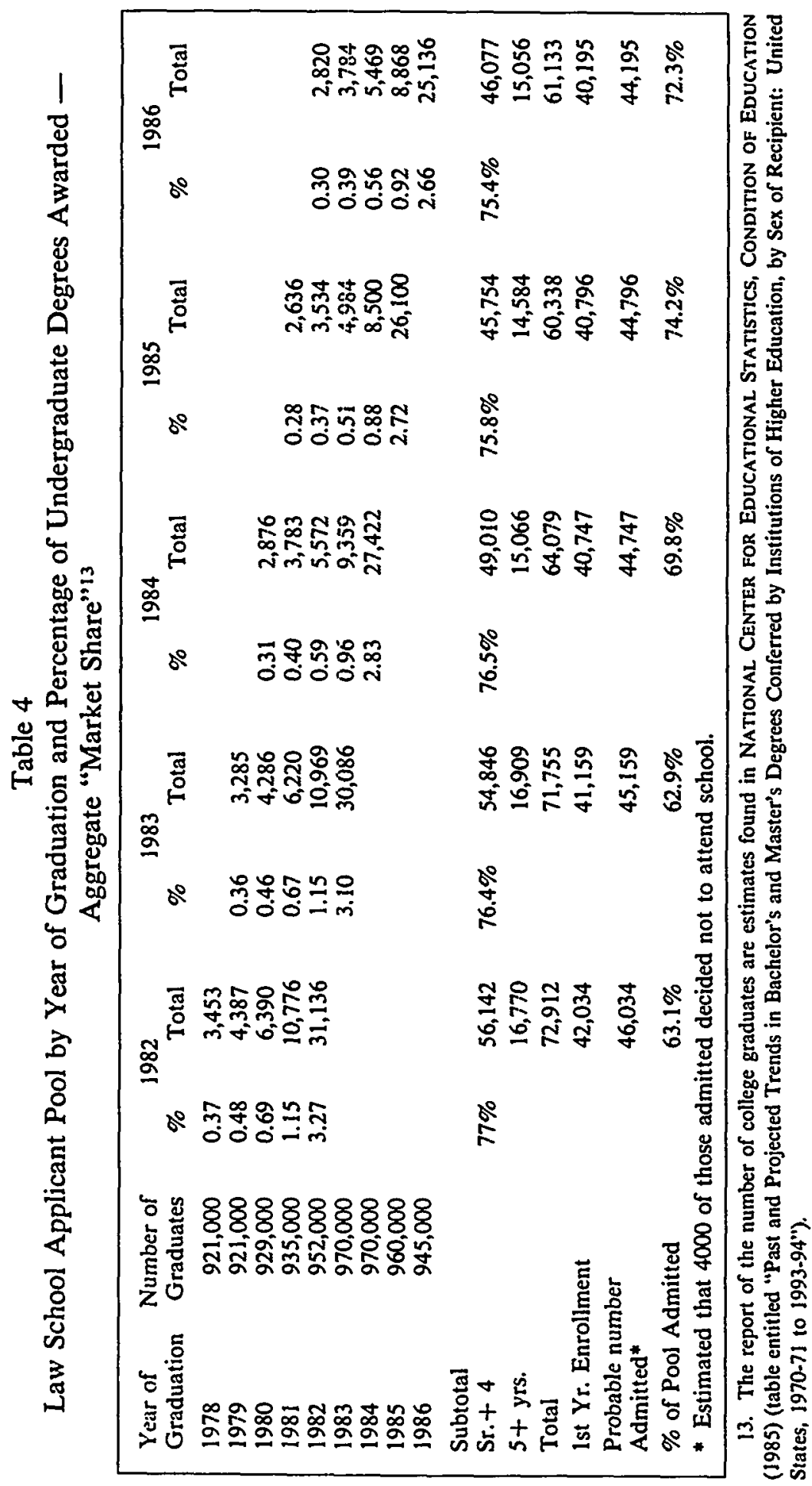


number of male applicants, whereas the number of female applicants declined only $0.3 \%$. The number of semior applicants from the West and South declined only $1 \%$ over this period.

Table 4 shows the trend in the number of law school applicants froin 1982 to 1986 by the year in which the applicants earned their undergraduate degrees. It also reflects the percentage of all students earning degrees that year who applied to law school. Thus, $0.37 \%$ (3453) of the 921,000 persons who graduated in 1978 apphed to. law school in 1982, while $3.27 \%(31,136)$ of the 952,000 persons who graduated in 1982 applied that same year. The 1982 law school applicant pool also included 10,776 persons who graduated in 1981 (1.15\% of the graduating class), as well as 6390 persons from the class of 1980 and 4387 persons froin the class of 1979. A similarly detailed presentation is made of the four applicant pools froin 1983 througl 1986. The pattern is shown graphically in Figure III.

Minority applicants constituted 17\% of the applicant pool in 1986 as compared to $14 \%$ in 1982 . The number of caucasian applicants fell 11,717 froin 1982 to 1986 -from 62,307 applicants in 1982 to 50,590 applicants in 1986. Since the total number of applicants decreased by 11,779 during that time, virtually the entire decrease in the number of applicants is attributable to decisions by caucasians to seek careers in fields other than law. As Table 5 indicates, over the five admission years, none of the identifiable minority groups in the pool declined as much as the applicant pool as a whole.

Table 5

Ethnic Composition of the Applicant Pool: 1982 and 1986

\begin{tabular}{|lrrc|}
\hline Ethnic Group & 1982 & 1986 & $\%$ Change \\
Native American & 331 & 359 & +8 \\
Black & 4,717 & 4,406 & -7 \\
Caucasian & 62,307 & 50,776 & -18 \\
Mexican American & 904 & 815 & -10 \\
Hispanic & 1,074 & 1,284 & +19 \\
Asian American & 1,182 & 1,270 & +7 \\
Puerto Rican & 1,087 & 952 & -12 \\
Other Minority & 1,310 & 995 & -24 \\
TOTAL POOL & 72,912 & 61,133 & -16 \\
\hline
\end{tabular}

There were 9\% fewer female applicants in 1986 than in 1982, while the number of male applicants fell by $20 \%$ over the same time period. Although the number of female applicants decreased by approximately 


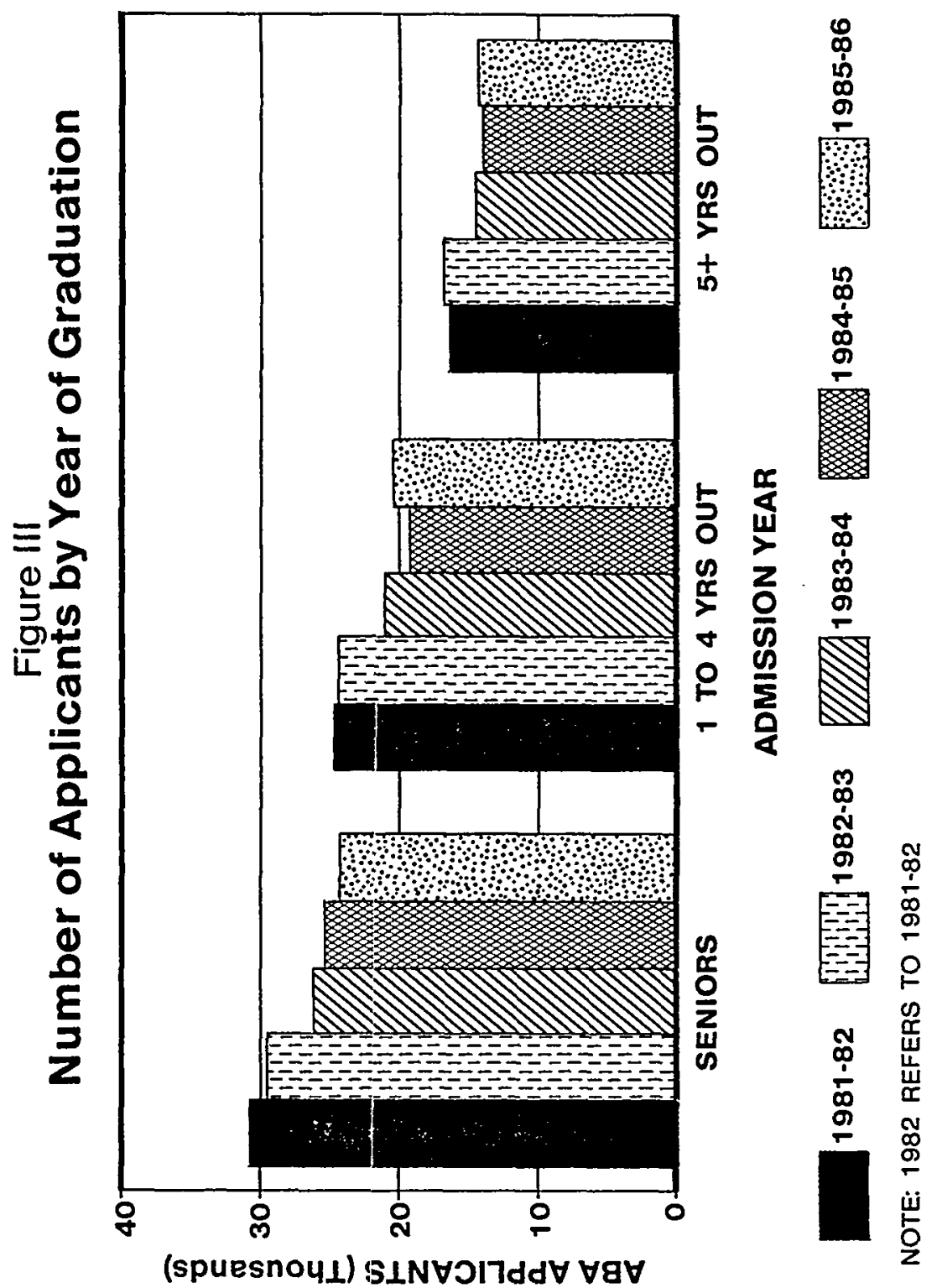


2800 during the five admission years, the percentage of female applicants in the pool increased 3\%, from $38 \%$ in 1982 to $41 \%$ in 1986.

\section{The SOURCE AND QUALITY OF THE NATIONAL APPLICANT POOL: 1982-1985}

Table 6 indicates the kinds of undergraduate institutions most law school applicants attend. ${ }^{14}$ The table shows that approximately $76 \%$ of the law school applicants earned degrees at public and private universities and four-year nonsectarian colleges (categories 1-6 and 11-14 in Table 6). Approximately $56.5 \%$ of the apphicant pool in 1982 and $55.3 \%$ in 1986 came froin public universities whose entering students had mean SATs of 1000 or higher, private universities whose entering students had mean SATs of 1050 or higher, and four-year private nonsectarian schools whose entering students had niean SATs of 1025 or higher. ${ }^{15}$

The most highly selective institutions as defined by the Astin Survey ${ }^{16}$-those with student bodies having the highest mean SAT scores (categories 3, 6, and 14 in Table 6)-provided $40.1 \%$ of the applicant pool in 1982 and $34.5 \%$ in 1986. In both percentages and absolute numbers, the decline in applications from graduates of the most highly selective schools has been larger than the decline in applications from graduates of other schools. Thus, fron 1982 to 1986, the decline in applicants from the most highly selective public umiversities was $20 \%$, while the decline in applicants from private universities and four-year nonsectarian colleges was $23 \%$ and $29 \%$ respectively. During the same period, the overall size of the applicant pool declimed $16.2 \%$.

14. The unidentified applicants attended undergraduate institutions either not included in the Astin survey or omitted from the report in Table 6 because they provided so few applicants to law school.

15. The enrollment figures are found in the 1985 REPORT, supra note 7 , at 66 . The figures include only ABA-approved law schools. The 1985 data include three schools that were approved after 1982; 517 of the entering students reported in 1985 enrolled in schools that were not included in the 1982 totals. Thus, if the 1985 enrollment figures are compared with the 1982 figures for schools appearing in both reports, the entering classes at approved schools fell from 42,034 to 40,502 , a $3.7 \%$ decline. If the gross figures are used, the decline is $3 \%$.

16. The division of undergraduate institutions into 38 categories follows the classification pattern established by Professor Alexander Astin and his colleagues in their survey of attitudes and opinions of college freshmen. See A. Astin, K. GREEN, W. KORN \& M. Schalit, The AMERICAN FreshmaN: NATIONAL NormS for FALl 1986 (1986). Since 1966, over 1200 schools have participated in the Astin Freshman Surveys. The Astin data are generated for a given year, however, from a much smaller number of schools. For example, in 1986, 2717 institutions were invited to participate. Five hundred and sixty accepted the invitation, but only 552 provided data in time for the report. Of these, 372 supplied information that was sufficiently complete to be used in computing the national norms. 
Table 6

Undergraduate Schools Providing Law School Applicants: Classified by Kind of School and Mean SAT of Entering Freshmen ${ }^{17}$

\begin{tabular}{|c|c|c|c|c|c|c|c|}
\hline $\begin{array}{l}\text { School } \\
\text { SAT Mean }\end{array}$ & Category & $\begin{array}{c}1982 \\
\text { Applicant } \\
\text { Pool }\end{array}$ & $\begin{array}{c}1983 \\
\text { Applicant } \\
\text { Pool }\end{array}$ & $\begin{array}{c}1984 \\
\text { Applicant } \\
\text { Pool }\end{array}$ & $\begin{array}{c}1985 \\
\text { Applicant } \\
\text { Pool }\end{array}$ & $\begin{array}{c}1986 \\
\text { Applicant } \\
\text { Pool }\end{array}$ & $\begin{array}{c}\% \\
\text { Decrease } \\
1982-86\end{array}$ \\
\hline $\begin{array}{l}\text { Public Universi } \\
<1000 \\
1000-1099 \\
>1099 \\
\text { TOTAL }\end{array}$ & sity & $\begin{array}{r}5234 \\
5218 \\
7908 \\
18,360\end{array}$ & $\begin{array}{r}5133 \\
5236 \\
7572 \\
17,941\end{array}$ & $\begin{array}{r}4366 \\
4830 \\
6540 \\
15,736\end{array}$ & $\begin{array}{r}4149 \\
4422 \\
6358 \\
14,929\end{array}$ & $\begin{array}{r}4118 \\
4373 \\
6322 \\
14,813\end{array}$ & $\begin{array}{l}21.3 \\
16.2 \\
20.1 \\
19.3\end{array}$ \\
\hline $\begin{array}{l}\text { Private Univers } \\
<1050 \\
1050-1174 \\
>1174 \\
\text { TOTAL }\end{array}$ & $\begin{array}{r}\text { csity } \\
4 \\
5 \\
6\end{array}$ & $\begin{array}{r}3151 \\
2447 \\
6295 \\
11,893\end{array}$ & $\begin{array}{r}3136 \\
2334 \\
5963 \\
11,433\end{array}$ & $\begin{array}{l}2756 \\
2071 \\
5135 \\
9962\end{array}$ & $\begin{array}{l}2674 \\
1947 \\
4868 \\
9489\end{array}$ & $\begin{array}{l}2594 \\
2078 \\
4864 \\
9536\end{array}$ & $\begin{array}{l}17.7 \\
15.1 \\
22.7 \\
19.8\end{array}$ \\
\hline $\begin{array}{l}\text { 4-Yr.Public Co } \\
<935 \\
935-1024 \\
>1024 \\
\text { TOTAL }\end{array}$ & $\begin{array}{r}\text { ollege } \\
7 \\
8 \\
9\end{array}$ & $\begin{array}{r}1682 \\
2221 \\
896 \\
4799\end{array}$ & $\begin{array}{r}1860 \\
2260 \\
799 \\
4919\end{array}$ & $\begin{array}{r}1654 \\
1981 \\
727 \\
4362\end{array}$ & $\begin{array}{r}1490 \\
1920 \\
722 \\
4132\end{array}$ & $\begin{array}{r}1546 \\
1838 \\
781 \\
4165\end{array}$ & $\begin{array}{r}8.1 \\
17.3 \\
12.8 \\
13.2\end{array}$ \\
\hline $\begin{array}{l}\text { 4-Yr.Private } N \\
<950 \\
950-1024 \\
1025.1174 \\
>1174 \\
\quad \text { TOTAL }\end{array}$ & $\begin{array}{c}\text { Jonsectari } \\
11 \\
12 \\
13 \\
14\end{array}$ & $\begin{array}{r}460 \\
666 \\
2264 \\
3533 \\
6923\end{array}$ & $\begin{array}{r}493 \\
681 \\
2180 \\
3289 \\
6643\end{array}$ & $\begin{array}{r}453 \\
599 \\
1965 \\
2740 \\
5757\end{array}$ & $\begin{array}{r}471 \\
596 \\
1790 \\
2565 \\
5422\end{array}$ & $\begin{array}{r}426 \\
582 \\
1826 \\
2523 \\
5357\end{array}$ & $\begin{array}{r}7.4 \\
12.6 \\
19.4 \\
28.6 \\
22.6\end{array}$ \\
\hline $\begin{array}{l}\text { 4-Yr. Catholic } \\
<950 \\
950-1024 \\
>1024 \\
\text { Unknown } \\
\text { TOTAL }\end{array}$ & $\begin{array}{l}16 \\
17 \\
18 \\
19\end{array}$ & $\begin{array}{r}489 \\
1066 \\
1403 \\
\\
2958\end{array}$ & $\begin{array}{r}532 \\
1016 \\
1403 \\
3 \\
2954\end{array}$ & $\begin{array}{r}490 \\
952 \\
1187 \\
6 \\
2635\end{array}$ & $\begin{array}{r}480 \\
885 \\
1192 \\
4 \\
2561\end{array}$ & $\begin{array}{r}490 \\
855 \\
1203 \\
6 \\
2554\end{array}$ & $\begin{array}{c}0 \\
19.8 \\
14.3 \\
\\
13.7\end{array}$ \\
\hline $\begin{array}{l}\text { 4-Yr. Protestan } \\
<875 \\
875.974 \\
975-1049 \\
>1049 \\
\text { TOTAL }\end{array}$ & $\begin{array}{l}20 \\
21 \\
22 \\
23\end{array}$ & $\begin{array}{r}264 \\
520 \\
837 \\
1606 \\
3227\end{array}$ & $\begin{array}{r}265 \\
474 \\
846 \\
1553 \\
3138\end{array}$ & $\begin{array}{r}232 \\
415 \\
712 \\
1414 \\
2782\end{array}$ & $\begin{array}{r}221 \\
394 \\
666 \\
1162 \\
2443\end{array}$ & $\begin{array}{r}246 \\
437 \\
638 \\
1247 \\
2568\end{array}$ & $\begin{array}{r}6.8 \\
16.0 \\
23.8 \\
22.4 \\
20.4\end{array}$ \\
\hline $\begin{array}{l}\text { Predominantly } \\
\text { Public 4-yr. } \\
\text { Private 4-yr. } \\
\text { Not } \\
\text { Identified }\end{array}$ & $\begin{array}{c}\text { Black Co } \\
34 \\
35 \\
36\end{array}$ & $\begin{array}{r}\text { llege } \\
275 \\
522 \\
23,955\end{array}$ & $\begin{array}{r}272 \\
487 \\
23,968\end{array}$ & $\begin{array}{r}275 \\
484 \\
22,086\end{array}$ & $\begin{array}{r}275 \\
478 \\
20,619\end{array}$ & $\begin{array}{r}285 \\
469 \\
21,386\end{array}$ & $\begin{array}{r}+3.6 \\
10.2\end{array}$ \\
\hline TOTAL & & 72,912 & 71,755 & 64,079 & 60,339 & 61,133 & 16.2 \\
\hline
\end{tabular}

With the number of applicants from the most highly selective undergraduate programs falling at a faster rate than the number of applicants from other schools, it is not surprising that there has been a decline in the

17. The undergraduate institutions included in the data in Table 6 supply approximately twothirds of the applicants to law schools and are a representative sample of all undergraduate institutions. 
overall academic credentials, as measured by a combination of LSAT scores and GPAs, of those in the applicant pool. Thus, the number of persons in the top end of the applicant pool-those with LSAT scores of 34 or higher coupled with GPAs of 3.25 or higher-fell from 18,079 in 1982 to 13,048 in 1986 , a decline of $27.8 \%$, as compared with the $16.2 \%$ decline in the number of applicants overall. The number of applicants with LSAT scores of 30 or higher and undergraduate GPAs of 3.0 or higher fell from 32,735 to 24,585 over the same period, a $24.9 \%$ decline. By contrast, the bottom end of the pool-occupied by applicants with LSAT scores below 30 and GPAs below 3.0-remamed remarkably stable, with 13,771 apphicants in the 1982 pool and 13,144 in the 1986 pool, a decline of only $4.6 \% .^{18}$

In a real sense, the relative stability at the low end of the pool has masked the qualitative significancc of the decline in the size of the pool. And there is no indication that the qualitative decline has reached its nadir. Between 1985 and 1986, when the size of the applicant pool increased by $1.1 \%$, the number of applicants presenting LSAT scores of 34 or higher and GPAs of 3.25 or ligher decreased by $1.1 \%$, from 13,237 to 13,048. The group with LSAT scores of 30 or higher and GPAs of 3.0 or higher was unchanged. Even if the size of the applicant pool remains constant or increases shightly, the academic credentials of those in the pool may continue to decline.

Figure IV helps put the declining academic credentials in context. Assuming that every applicant in the pool with an LSAT score of 34 or higher and a GPA of 3.25 or higher was enrolled in law school, only $32 \%$ of the 1986 entering class would have such credentials as compared to $43 \%$ of the entering class in 1982 . If we make the same assumption about those with LSAT scores of 30 or higher and GPAs of 3.0 or higher, $61 \%$ of the 1986 entering class would present credentials at that level, as compared to $78 \%$ of the entering class in 1982 . Of course, the assumption that all were admitted and all enrolled is inconsistent with the facts. All were not admitted (although they could have been had they applied to different law schools ${ }^{19}$ ) and all who were admitted did not attend law school.

18. The number of black applicants in the pool fell from 4717 in 1982 to 4516 in 1986 , or $4.3 \%$. The number of black applicants with LSATs of 34 or higher and GPAs of 3.25 or higher rose from 77 in 1982 to 86 in 1986, and the number with LSATs of 30 or higher and GPAs of 3.0 or higher fell from 294 in 1982 to 286 in 1986. In essence, the academic credentials of black applicants remained constant over the five years.

19. A great many applicants restrict their applications to schools that are unlikely to admit them. These applicants do so because they lack information about the probability of admission, or they determine not to attend law school unless admitted to a specific school or a group of schools, or they have personal circumstances that restrict mobility. Thus, more than $40 \%$ of the applicants 


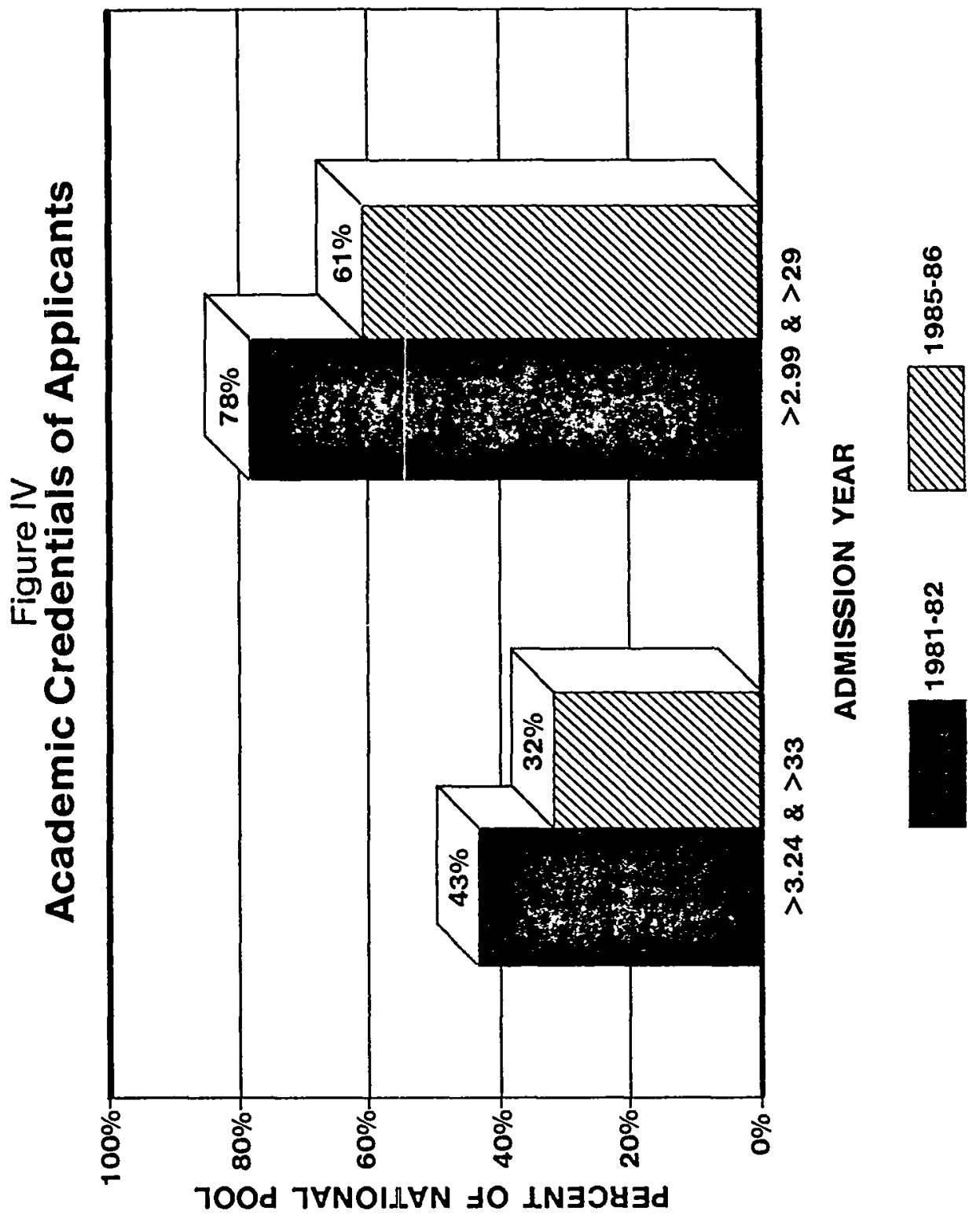




\section{Decline In Quality AND Quantity Coupled WITH STABLE ENROLLMENTS}

The enrollment figures over the five-year period in question have reinained stable. From 1982 to 1985, first-year enrollment dropped only $3 \%$, from 42,034 to 40,796.20 In 1986, enrollment dropped a further 601 to 40,195 , a decline of $1.5 \%$, although the apphicant pool increased by $1.1 \%$. In sum, froin 1982 to 1986 , enrollment dechined $4.4 \%$ while the applicant pool fell $16.2 \%$.

If one assumes conservatively that approximately 4000 , or slightly less than $10 \%$, of those admitted by at least one school decide not to attend law school during the year of their admission, the law schools collectively will have admitted 46,034 applicants in 1982 for a yield of 42,034 and 44,195 in 1986 for a yield of 40,195. With 72,912 applicants in 1982 and 61,133 in 1986, law schools nationally moved from admitting $63 \%$ of all applicants in 1982 to admitting $72 \%$ of the pool in 1986, and they did it during a period when the academic credentials of those in the pool were falling. Nationally, the academic credentials of the 1986 law school entering class were lower than those of the 1982 entering class.

If the 1986 pool of 61,133 shrinks approximately $10 \%$ to a pool of 55,000 , eight out of every ten applicants will have to be admitted simply to inaintain an entering class of 40,195 . And if present trends continue and the $10 \%$ decline in the size of the applicant pool is accompanied by a $15 \%$ decline in the number of applicants with LSATs of 34 or higher and GPAs of 3.25 or higher and all in the group were admitted and enrolled, each school would have sixty-four entering students with those credentials if the students were spread equally among all law schools. Since the

who apply to a single law school are not admitted. An effort has been made to broaden the information base available to applicants. LSAC/LSAS, THE RIGHT LAW SCHOOL FOR YOU (1986).

20. Enrollment figures are found in the 1985 REPORT, supra note 7, at 66 . The decline in firstyear enrollment is actually $4.4 \%$ rather than $3 \%$ if one adjusts for law schools included in the 1985 Report but not in the 1982 Report. See supra note 7. Whether the enrollment decline is viewed as being $3 \%$ or $4.4 \%$, the fact remains that enrollment declined at a much slower rate than the applicant pool itself. The figures reported by the ABA are widely distributed and are used in this article for the sake of consistency. The conclusion would be the same regardless of which figures are used.

Notwithstanding that first-year enrollment fell only $3 \%$ from 1982 to 1985, first-year enrollment at 99 of the 173 law schools fell between 1982 and 1985. Forty-five of the sclools experienced drops in first-year enrollment of less than $10 \%, 26$ experienced drops from $10 \%$ to $19.9 \%, 17$ experienced drops from $20 \%$ to $29.9 \%, 8$ experienced drops from $30 \%$ to $39.9 \%$, and 3 experienced drops from $40 \%$ to $40.9 \%$. Relatively small increases at the other schools coupled with two schools increasing the size of their entering class by more than $30 \%$ counterbalanced the reductions in the size of the first-year class experienced by the 99 schools. Only 18 schools increased the size of their entering classes by more than $10 \%$. Of those schools, four increased their size by $20 \%$ or more. The calculations are based on information in the 1982 REPORT and the 1985 REPORT, supra note 7.

The 1972-1985 enrollment increase for the 147 schools approved by the ABA prior to 1972 was relatively modest, with the entering classes being 34,402 and 35,159 for 1972 and 1985 respectively. 
stronger schools will continue to syphon off a disproportionate number of applicants with the highest credentials, substantially fewer than sixtyfour students with those credentials would be available to the other schools. ${ }^{21}$

Table 7

Ranking of Law Schools by Average LSAT Scores

\begin{tabular}{|cc|}
\hline School Ranking & Average LSAT \\
1 to 19 & 40 to 45 \\
20 to 30 & 39 \\
31 to 38 & 38 \\
39 to 50 & 37 \\
51 to 70 & 36 \\
71 to 82 & 35 \\
83 to 103 & 34 \\
104 to 116 & 33 \\
117 to 131 & 32 \\
132 to 149 & 31 \\
150 to 158 & 30 \\
159 to 163 & 29 \\
164 to 169 & 14 to 27 \\
\hline
\end{tabular}

To test the assumption that the dechine in the size and quality of the law school applicant pool has been felt by almost all schools over the past five years, not just the weaker ones, we ranked law schools from high to low (1 to 169) by using the average LSAT scores of enrolled students. ${ }^{22}$ Table 7 sets forth that ranking. We then assigned an index number to each person in the applicant pool, using a formula that took into account the applicant's combined LSAT score and undergraduate GPA. ${ }^{23}$ Under the formula, a student with a 48 LSAT and 4.0 GPA would have an index rank of 95, and one with a 10 LSAT and a 2.0 GPA would have an index rank of 14. As Table 8 indicates, on average it was soinewhat

21. Many schools do not consider academic credentials of a 34 LSAT and a 3.25 GPA to be outstanding. Using the index described infra note 23, such credentials would yield an index of 65 and place the applicant in the middle of those admitted and enrolled.

22. If an applicant had taken the LSAT more than once, the average score for that applicant was used in calculating the score used in the study. The available data included information from 169 of the 175 ABA-approved schools. In an effort to present a ranking that was not skewed by the scope of an individual school's affirmative action program, the average LSAT was calculated by using the top $80 \%$ of each school's LSAT scores.

23. The index was created by use of the following formula:

$$
\text { Index }=(14 \times \text { GPA })+(1.4 \times \text { LSAT })-28 .
$$

This index reflects a fairly typical law school weighting of GPA and LSAT in initial admissionsorting formulas. The index would be zero for an applicant with a 10 LSAT and a 1.0 GPA, and 100 for an applicant with a 48 LSAT and a 4.33 GPA. 
Table $8^{24}$

Nonminority Applicants: Admission and Enrollment by LSAT-GPA Index and Rank of Law School

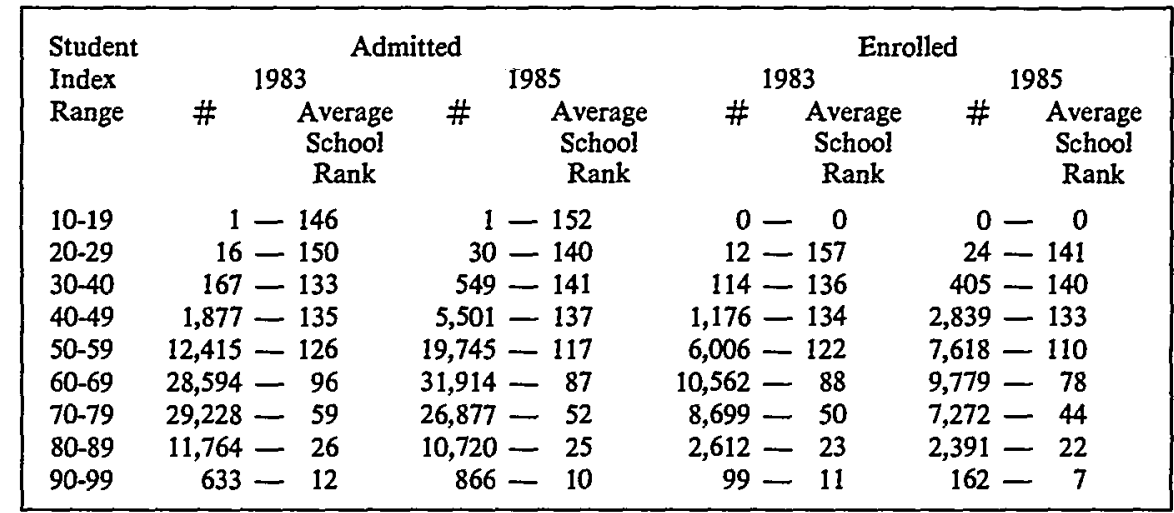

easier for students with lower credentials (less than an index of 50) to be admitted to a more highly ranked school in 1985 than it was in 1983.25 The shift during the three-year period, although not dramatic, was consistent for students with indices of 50 or higher. Thus, the average ranking of law schools attended by students in the 60-69 index range was 78 for those enrolling in 1985 as compared to a ranking of 88 two years earlier. The average school ranking for those in the 50-59 index range climbed twelve places (from 122 to 110 ) during the same period, and enrollees in the 70-79 index range climbed six places in the ranking. The admissions process followed a sinilar pattern. ${ }^{26}$

The figures in Table 8 belie the notion that the coinbined quantitative-qualitative decline in the applicant pool has been felt only by schools at the lower end of the pecking order. Although the effect has been inconsequential at the most selective schools, nearly all law schools are

24. The enrollment figures set forth in Table 8 are taken from the LSAC/LSAS's data bank and are not complete. Over three-quarters of the nonminority students in the entering classes are represented, i.e., 29,203 enrolled students in 1983 and 30,490 enrolled students in 1985 .

Because the LSAC/LSAS data bank focuses primarily on admission data, the figures on the number of applications accepted, while not including all of those admitted, are somewhat more complete-84,695 in 1983 and 96,203 in 1985. The figures, of course, include multiple admissions granted to many of the applicants.

25. The 1983 figures were used to avoid a possible skewing that might occur in converting the 1982 LSAT scores to the new 10 to 48 range.

26. Minorities and other subgroups have had experiences that differ from the general patterns. For example, the figures in Table A show a somewhat different pattern for black applicants. The average rank of schools to which black applicants were admitted and at which they enrolled remained relatively constant. The lack of a pattern may reflect the fact that the number of applicants involved is relatively small or the fact that affirmative action programs in place in 1983 remained in place. 
now admitting and enrolling at least some students who would not have been admitted a few years ago. Figure $\mathrm{V}$ illustrates the scope of the change. The decline in the number of applicants with relatively high academic credentials undoubtedly means that for most schools (not just those at the bottom of the hierarchy), the top layer of students is somewhat thinner now than it was in 1983. The ripple effect stemming from the apparent perception among applicants of a qualitative law school hierarchy, which we discussed in an earlier article, apparently has come to pass. In that article we hypothesized that the process was as follows:

For purposes of analysis, assume that Schools $X, Y$, and $Z$ had completely overlapping application pools, that, if given a choice, all applicants to the three schools preferred $X$ over $Y$, and $Y$ over $Z$, that all three schools suffered a 20 percent decline in applicant pools, and that all three decided to maintain the size of their entering class. To maintain its size, School $X$ was forced to accept people it would have rejected in the recent past. By hypothesis, all of those admitted who would not have been admitted by $X$ in prior years opted to attend $X$ rather than $Y$. While $X$ 's overall yield ratio may have fallen relatively little because so many at the low end decided to enroll, the overall academic credentials of those who enrolled declined to a greater extent than the drop in the average yield ratio might suggest. School $X$ 's action not only changed the academic credentials of its own entering class, but had a sharp impact on the credentials of those enrolling at $Y$ and $Z$. [ $Y$, having lost the top of its entering class to $X$, will dip down in its pool and admit the top of $Z$ 's entering class to make up the

Table A

Black Applicants: Admission and Enrollment by LSAT-GPA Index and Rank of Law School

\begin{tabular}{|c|c|c|c|c|c|c|c|c|}
\hline \multirow{3}{*}{$\begin{array}{l}\text { Student } \\
\text { Index } \\
\text { Range }\end{array}$} & \multicolumn{4}{|c|}{ Admitted } & \multicolumn{4}{|c|}{ Enrolled } \\
\hline & \multicolumn{2}{|r|}{1983} & \multicolumn{2}{|r|}{1985} & \multicolumn{2}{|r|}{1983} & \multicolumn{2}{|r|}{1985} \\
\hline & $\#$ & $\begin{array}{c}\text { Average } \\
\text { School } \\
\text { Rank }\end{array}$ & 㭌 & $\begin{array}{c}\text { Average } \\
\text { School } \\
\text { Rank }\end{array}$ & $\#$ & $\begin{array}{c}\text { Average } \\
\text { School } \\
\text { Rank }\end{array}$ & $\#$ & $\begin{array}{c}\text { Average } \\
\text { School } \\
\text { Rank }\end{array}$ \\
\hline $10-19$ & & -161 & & -117 & & -163 & & -113 \\
\hline $20-29$ & 38 & -140 & 76 & -135 & 21 & -142 & 61 & -138 \\
\hline $30-39$ & 389 & -122 & 592 & -121 & 220 & -115 & 356 & -119 \\
\hline 40.49 & 1040 & -93 & 1555 & -95 & 452 & -85 & 611 & -91 \\
\hline $50-59$ & 1548 & -65 & 1585 & -64 & 463 & 59 & 415 & -55 \\
\hline $60-69$ & 1027 & -39 & 919 & -40 & 236 & 28 & 196 & -34 \\
\hline $70-79$ & 368 & - & 206 & -25 & 72 & 15 & 39 & -24 \\
\hline $80-89$ & 54 & - & 36 & -25 & 6 & - & & -3 \\
\hline
\end{tabular}

Although the figures do not refiect an enroliment movement from 1983 to 1985 to more highly ranked schools, they do indicate that affirmative action is a reality in law school admissions. Comparison of the data presented in Table 8 and Table $A$ indicates that in 1985 the average ranking of schools attended by nonminority applicants in the 60 to 69 index range was 78 as compared to the average ranking of 34 for black applicants that year. Comparable figures for students in the 70 to 79 index range are 44 for nonminorities and 24 for blacks. As with the figures in Table 8 , the data for enrollment and admission figures in Table $A$ are not complete. 


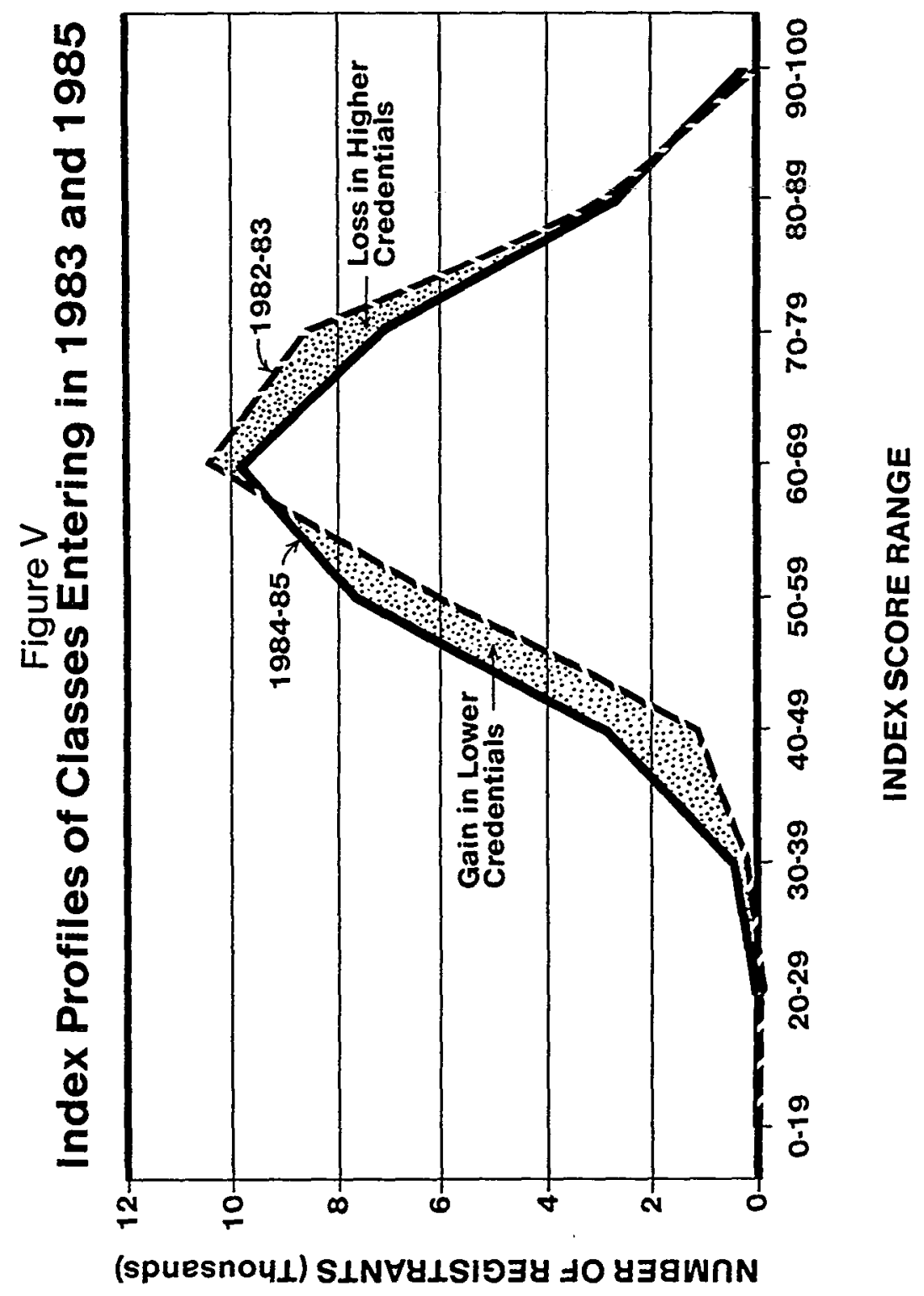




\section{difference.] ${ }^{27}$}

The figures in Table 8 reflect the ripple effect described above. Most law schools (even among the seventy or so that reasonably view themselves as being ranked in the top twenty or twenty-five schools ${ }^{28}$ ) seem to have enrolled students in 1985 with somewhat lower academic credentials than they did two years earlier. The shift in quality at the stronger schools is only at the margins and, thus, the change in quality has not required either a change in program or in grading patterns. The same cannot be said for many schools at the lower end of the hierarchy.

If the number of applicants who are among the "best and brightest" continues to decline, however, the marginal qualitative shifts may continue at many schools, even if the size of the pool stabilizes, unless enrollment size is reduced. And if the pool continues to decrease in size (even as little as $10 \%$ ) while enrollment remains constant, the qualitative problems at many "strong" schools may become noticeable and call for adjustments in size, educational programs, or grading patterns.

\section{Undergraduate Freshman Attitudes ABOUT LAW SCHOOL}

Over the course of more than twenty years, Alexander Astin and his colleagues have been conducting a highly regarded survey of opinions and attitudes on campuses. ${ }^{29}$ Each year, freshmen at more than 500 institutions are questioned. Astin measures expectations about legal education by asking freshmen whether they intend to earn a J.D. degree or become lawyers. If the attitudes expressed by freshmen persist through the undergraduate years, a decline in interest expressed in the fall of 1980 may be reflected in a decline in the number of seniors who apply to law school during the 1983-84 admission year. Because so many undergraduates take more than four years to earn their degrees, of course, the impact of changes in attitude on the law school applicant pool three years later would be attenuated; the changes in attitude, however, may affect the applicant pool for several years.

There has been a decline in interest in attending law school among freshmen. Figure VI depicts the percentage of freshmen at public and private universities (categories 1-6 in Table 6) who start their undergraduate work with an expectation of earning a J.D. Compared with the freshmen at public universities, more than twice the percentage of freshmen at private universities anticipate going to law school. Interest in

27. Vernon \& Zimmer, supra note 3, at 266.

28. See infra note 36 .

29. The results of the 1986 survey are found in A. Astin, K. GREEN, W. KorN \& M. Schalit, supra note 16. 


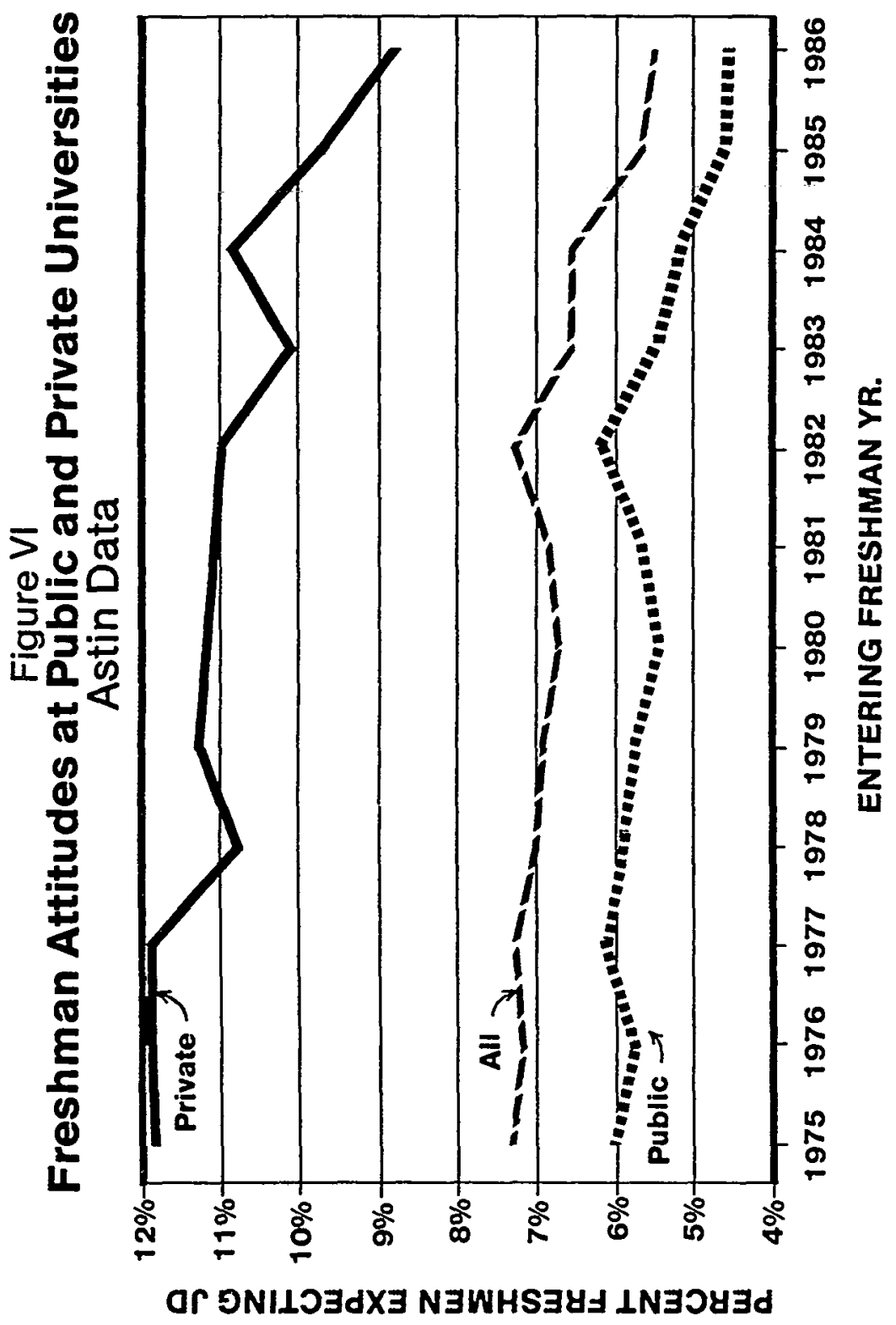


legal education among freshman at private universities, however, has declined from a high of $11.9 \%$ in 1977 to a low of $8.8 \%$ in 1986. Interest among freshmen at public universities held reasonably steady at slightly below $6 \%$ until it peaked at $6.2 \%$ in 1982 . It fell thereafter to $4.6 \%$ by 1986.

The difference in attitudes among male and female freshmen is reflected in Figure VII. Women's interest in legal education increased sharply in 1976 and 1977 , and, with a few minor deviations, continued to increase through 1983. Women's interest then declined fairly sharply in 1984 and 1985, and revived slightly in 1986. Shifts of interest among women have not exceeded $1 \%$, however, while men's interest fell from $6.2 \%$ to $3.7 \%$ over the same period. Because the magnitude of the shift in men's interest in legal education was almost three times greater than the magnitude of the shift in women's interest, the shifts in interest among men tend to dominate the overall figures. Except in 1982, male freshmen's interest in legal education declined steadily from 1975 through 1986.

Freshmen interest in legal education moved up in 1982, declined steadily over the next three years, reached a ten-year low in 1985, and recovered slightly in 1986. Figure VIII illustrates the trend in freshmen attitudes in highly selective public universities (category 3 in Table 6), the largest single source of law school applicants. Although fluctuations at highly selective public universities were wider than the national average (Figure VII), there was a 27\% decline in interest from 1982 through 1986. Compared with the national average, however, a much larger percentage of men and women freshmen at the highly selective institutions expressed an interest in legal education, as illustrated in Figure VII. This disparity is partly due to the fact that institutions such as two-year colleges and other non-law school feeder institutions are. included in the national base. The data in Figure VIII demonstrate that, since 1983, a higher percentage of women than men at highly selective public universities has expressed interest in attending law school.

In our earlier article, we noted that enrollment in undergraduate majors traditionally elected by students planning to attend law schoolthe social sciences (particularly political science) and the humanities (particularly history) - has fallen markedly. ${ }^{30} \mathrm{We}$ asked whether the declining interest in these areas might explain the declining interest in legal education, or whether the declining interest in legal education caused, at least in part, the declining interest in the particular subject matters. The Astin studies indicate that the decline in interest in legal education oc-

30. See Vernon \& Zimmer, supra note 3 , at 269. 


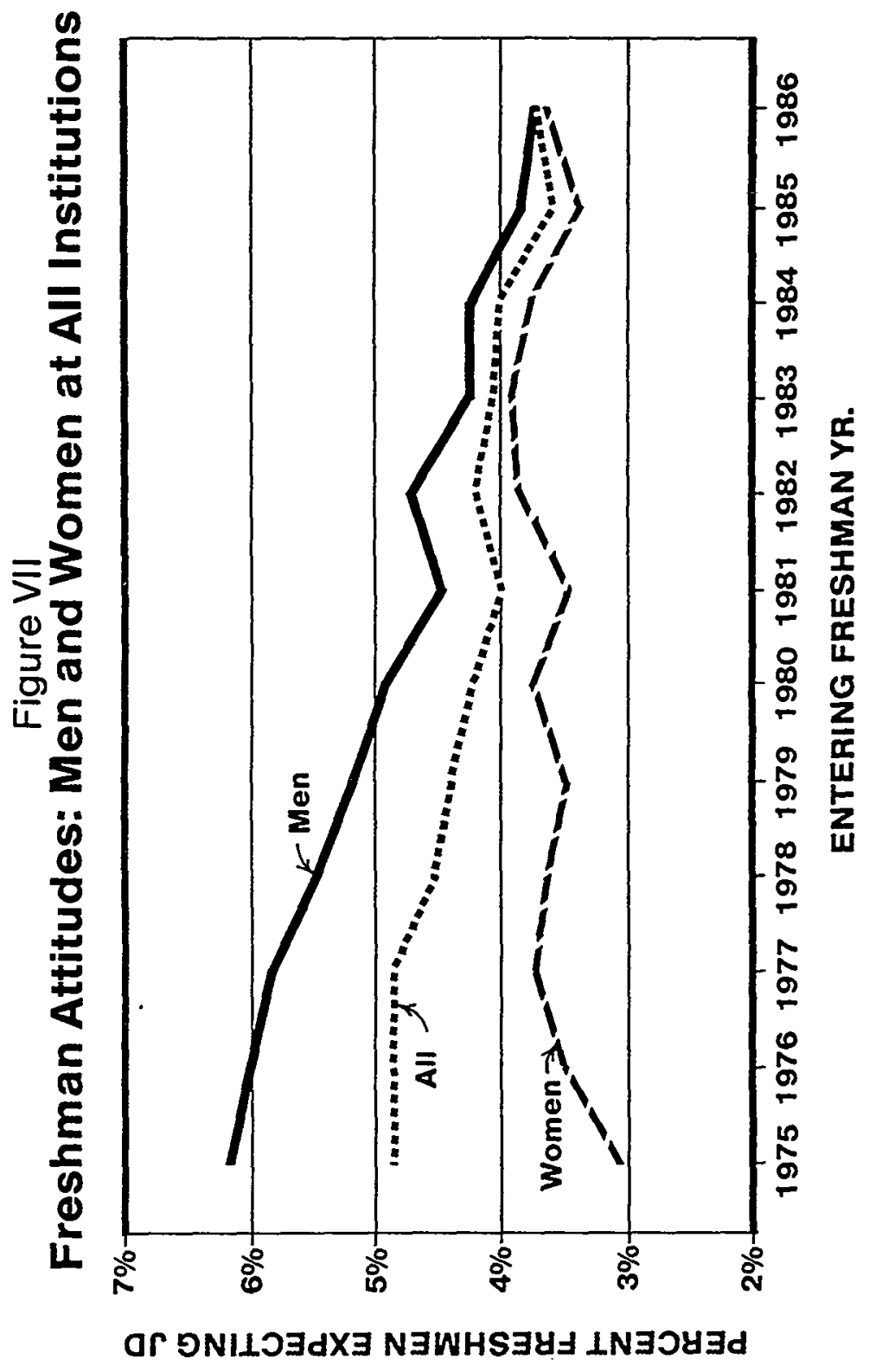




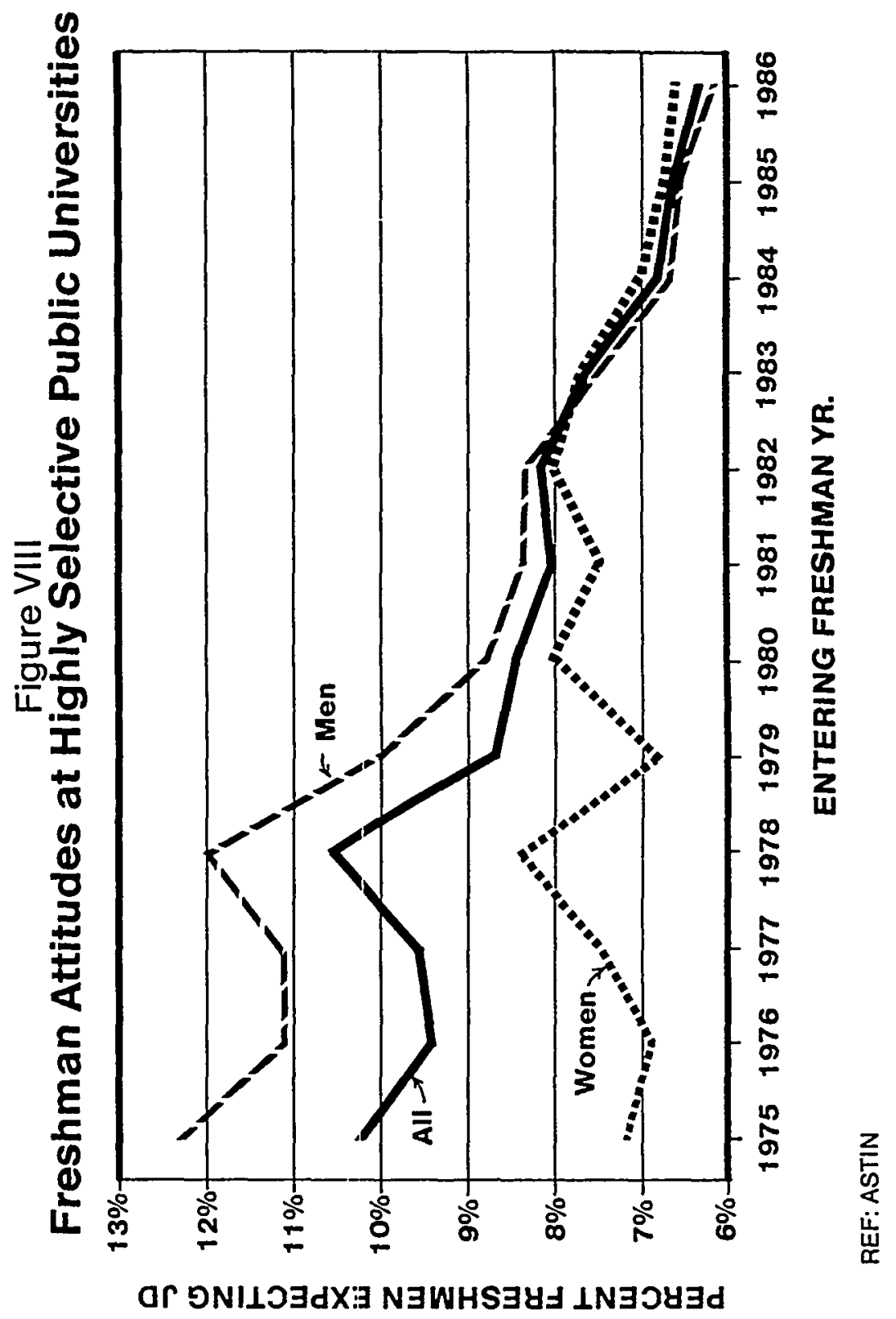


curs before most students select majors; it seems more likely, then, that the dechining interest in social sciences and liumanities stems from a shift in student imterest away from legal education rather than the reverse.

The reasons for the change in freshman attitudes about law school are not known. In our earlier article, we pointed out that the decline in interest was not unique and that interest in graduate professional education in general, including interest in dentistry, medicine, veterinary inedicine, and graduate business administration, had declimed during the 1980 's. ${ }^{31}$ The discussion in our earlier article focused on the likely factors that led college seniors and college graduates to decide not to apply to law school. As to those factors, we concluded that:

The most to be said is that a combination of elements rather than a single one probably caused the decrease in the pool and that at least some elements in the combination affected graduate professional education generally, including legal education. A shifting of undergraduate attention to vocational education and to engineering, computer science, and other technical fields, the increased availability of jobs resulting from an improved economy coupled with the high cost of attending graduate professional schools (both in time and money), and a perception that the financial returns following graduation are likely to be more modest than in the past because of perceived oversupply of lawyers functioned together to deter many potential applicants. 32

Althougl soine of the same reasons may influence freshman attitudes about legal education, the economic considerations involved are considerably more remote to freshmen than to seniors or college graduates who are already in the work force. Media, parents, and educators probably influence the freshman's attitude. High school counselors are probably playing a role in deflecting student interest in legal education. College freshmen would be in a better position to develop informed attitudes about a future in legal education and law practice if high school counselors were inade aware of relevant facts. ${ }^{33}$ Family attitudes strongly influence a child's perspective, and it may be that a worsening public perception of lawyers and the legal profession ${ }^{34}$ has contributed to the decline in interest in legal education among freshmen. Whatever the reasons, the Astin studies show that there has been a declining interest in law as a career.

31. Id. at $277-79$.

32. Id. at 281.

33. It well may be worth the effort for the various national associations to distribute informational materials to high school counselors.

34. See, e.g., What America Really Thinks About Lawyers and What Lawyers Can Do About It, Nat'1 L.J., Aug. 18, 1986, at S-1, col. 1. 


\section{The IMPlications OF THE DATA}

\section{A. The Qualitative Issues.}

The data concerning the decreasing size and quality of the applicant pool coupled with the data concerning the virtual maintenance of enrollment size by the law schools imdicate that law schools, faculty members, and the national legal education organizations must think hard about qualitative issues concerning the applicant pool. Key facts bearing on the qualitative issues indicate that the following occurred during the five admission years from 1982 through 1986:

1. The law school applicant pool fell $16.2 \%$, from 72,912 to 61,133 .

2. The number of law school applicants from the most selective undergraduate institutions decreased at a faster rate than the pool itself$20 \%$ for highly selective public universities, $23 \%$ for highly selective private universities, and $29 \%$ for the most selective nonsectarian fouryear colleges.

3. The number of applicants presenting the highest academic credentials (those with LSAT scores of 34 or higher and GPAs of 3.25 or higher) decreased by $27.8 \%$, a dechne that is greater than the $16.2 \%$ shrinkage in the pool size; and the number of applicants with such credentials continued to fall slightly between 1985 and 1986 when the size of the applicant pool increased somewhat.

4. The decline in academic credentials lias been felt, at least at the margins, by nearly all law schools, and the margins will expand at most schools if the size and quality of the applicant pool continue to decline.

5. The percentage of persons making up the applicant pool who were admitted by at least one school increased from $63 \%$ to $72 \%$, and the percentage admitted will increase to $80 \%$ if the size of the applicant pool decreases by another $10 \%$ and the size of the entering class remains constant.

6. The size of the law school entering class has remained relatively stable, falling from 42,034 to 40,195 .

Some schools have reduced their size by design in an effort to maintain quality; others have been forced to reduce their size because their applicant pools simply did not yield as many students as they sought. Leaving aside affirmative action considerations, many schools have maintained their size ${ }^{35}$ by accepting at least some students whose academic credentials were somewhat lower than the credentials of students accepted in 1983. In view of overhead costs steinming from investment in plant and library, and in view of the desire to maintain employment for faculty and staff, it is unlikely that many more schools will voluntarily reduce their enrollment by any sizable amount. 
Although a large percentage of law schools have felt the effects of a shrinking apphicant pool and a decline in the academic credentials of applicants, not all schools have been affected equally. The truly elite schools probably have not suffered any decline in quality. Schools in the next group-the fifty or so that consider themselves ranking among the top twenty or twenty-five schools ${ }^{36}$ - have seen the quality of their student bodies decline, at least marginally, but remam viable institutions of continuing quality. The seventy or eighty schools that rank themselves among the top fifty, but not among the top twenty-five, probably have suffered inore than inarginal qualitative dechines and must monitor their qualitative standards carefully. The twenty or so schools that make up the bottom tier of schools have suffered serious qualitative declines from a base that was not very high five years ago. They present special probleins that are discussed below. ${ }^{37}$ All in all, if the applicant pool over the next few years remams relatively stable both in size and quality, the overall quality of legal education in America will have suffered to some extent, but it will have suffered seriously only at the bottom tier of schools and, perhaps, a few of the seventy or so schools just above the bottom tier. If the size or the quality of the pool continues to decline even modestly, liowever, all but a handful of schools will face serious qualitative erosion unless the size of the entering class is reduced.

1. The Fifty Schools that Rank Themselves in the Top Twenty or Twenty-five. Assuming that law school enrollment is likely to remain relatively stable at least over the next few years, if there is no further sharp decline in the applicant pool, almost all of the fifty or so schools that rank themselves just below the inost selective schools will be able to maintam their size, grading norms, and education programs. For virtually all of these schools, maintenance of the status quo ante seems reasonable. Although students in the bottoin of their classes may not present credentials that are quite as strong as they were a few years ago, the differential in credentials will be inodest and therefore is unlikely to change performance levels substantially. ${ }^{38}$ Similarly, although most of these schools have lost some depth at the top of their classes, the qualita-

36. Once one gets past the 10 or so schools with entering students having average LSATs of 40 or higher and average undergraduate GPAs of 3.5 or higher, the next group of schools seems to have comparable student bodies, libraries, and physical plants, and each has differing strengths and weaknesses. Thus, for example, the school with a student body having an average LSAT of 36 may have a better faculty and library than a school with a student body having an average LSAT of 39 . It is not unreasonable for such schools, in light of their very real unique strengths, to believe that they rank among the top 20 or 25 schools. See E. Epstein, J. Shostak \& L. Troy, Barron's Guide to LAW ScHools 34-47 (6th ed. 1984) (comparing various law school rankings and resource indices).

37. See infra notes $42-43$ and accompanying text.

38. Where the bottom is weaker, bar examination results might reflect the changes. 
tive shift, although probably more than nominal, is not yet a cause for changing grading norms or program expectations. In essence, other than a slight increase in the number of " $D$ " and "F" grades assigned and, perhaps, a slight decrease in the number of " $\mathrm{A}$ " grades, these schools will continue as they have without fear of compromising the quality of their graduates.

The scenario described above for the stronger schools in the country assumes that both the number of applicants in the pool and the academic credentials of those applicants remain relatively stable. At least some of the fifty or so schools are at the qualitative edge, with a thinned top and an expanded bottom. Anything beyond a minor shrinkage in applicant pool size or quality will probably force faculties to rethink school size, grading norms, and, perhaps, program content. If pool size and academic credentials decline more than moderately, both the American Bar Association and the Association of American Law Schools (AALS), if they undertake to perform their appropriate functions, should play a major role in urging, and at times requiring, the necessary adjustments.

\section{The Seventy Schools that Rank Themselves Between the Top} Twenty-Five and Fifty. Most of the other seventy or so schools that view themselves ${ }^{39}$ as being among the top twenty-five to fifty schools in the country are very likely to have seen their applicant pool size and quality decline more than marginally. Each school in this group must make an individual judgment about the need to adjust size, grading norms, and program content. To the extent that the school's financial viability depends on enrollınent, either because of the dominance of tuition in the budget or because state appropriations are driven by enrollment figures, there is a serious tension between the desire to maintain academic standards and the desire to maintain faculty and staff jobs.

The tensions that some of these schools (both public and private) now face were at the foundation of the ABA's traditional determination to refrain from approving proprietary schools. Although the ABA has abandoned this position, ${ }^{40}$ the problems created by the tension between

39. The rationale set forth supra note 36 applies here as well.

40. The ABA's Standard 202 provides: "The law school shall be organized as a nonprofit educational institution and may not be operated for private profit." STANDARDS FOR APPROVAL OF LAW ScHOOLS Standard 202 (1986). Standard 203 provides in part: "The law schools shall be governed by a Board whose members . . . have no financial interest in the operation of the law school." Id. Standard 203.

Although the Standards have not been amended, in June 1977 and February 1979, the Council of the Section of Legal Education and Admissions to the Bar issued an interpretive statement that indicated its willingness to approve a proprietary school if it met all requirements other than the provisions quoted above. The interpretive statement provides that if the Council recommends to the 
survival (or profit) and quality remain. Botli the ABA and the AALS must now address the survival/quality problems that face many nonproprietary schools; these problems will only be exacerbated if the size of the applicant pool continues to drop. After many years in which the ABA and AALS reinspection process focused on encouraging educational quality well above the minimum, we suggest that, with respect to the seventy or so schools in question, the ABA and AALS are likely to shift their focus to identifying and insisting on minimum qualitative standards. Unless the two associations can deal effectively with the problem of deteriorating quality, there is a danger that some schools' very human desire to survive may override the appropriate insistence on quality.

When reinspecting the schools in question, the AALS and the ABA should focus primarily on evaluating the quality of each school's graduates and the quality of eacli school's educational program. The associations should review gradmg standards more closely than they have in the recent past. The ABA and the AALS have an obligation to protect the public's right to competent and well-educated counsel. Admittedly, it is not clear how the AALS and the ABA can judge whether a school's graduates meet a minimum qualitative standard. Although factors such as the quality of the plant and library, the level of financial support for the faculty, and the breadth of the curriculum reveal much about the richness of the educational experience provided by a law school, they rarely indicate whether a school's graduates meet a minimum qualitative level. As a starting point, however, the associations should review a law scliool's grading standards and the adinissions credentials of the student body.

Moreover, as distasteful as it may be to some in legal education, bar examination results should play a more important role in evaluating schools than they have in the recent past. Although a passing score on a bar examination obviously does not ensure minimum competence, the process is designed to filter out those who are clearly unqualified. Although bar examination results tell relatively little about the overall quality of a law school's educational program, information about a school's success rate on bar examinations is a valuable indicia of the quality of a substantial majority of a school's graduates.

Further, Multistate Bar Exammation (MBE) results may assist accrediting agencies in making minimum quality judgments. The MBE is a machine-graded test of basic subject matter that uses equating techniques to ensure as far as possible that the test yields comparable scores over the 
years. ${ }^{41}$ Accrediting agencies could make minimum quality judgments regarding a law school's graduates by noting deteriorating performances on the MBE over a three- to five-year period. MBE results obviously do not tell the full story. Just as LSAT scores are valuable but should not control admission decisions, MBE results alone should not control the qualitative judgment. The results would, however, be valuable as an element in the decision.

At present, MBE results are not considered in the accreditation process. As a general matter, they are currently available only through the various state boards of bar examiners. State boards could easily make annual reports to each law school, anonymously when appropriate, concerning the performance of its graduates on the MBE, and the law school could be required to report the resnlts to the accrediting bodies. If the accrediting bodies are to make a serious effort at evaluating the minimum quality of law school graduates, they must be given the appropriate tools.

If the accrediting bodies determine that minimum standards are not met, a decision may be made to condition continued ABA approval or AALS membership on reduced enrollment. Fairness dictates that the qualitative decision be made only after all available evidence has been considered. We have suggested that this evidence should include data concerning the academic credentials of entering students, the grading system, state bar examination results, and the MBE results. Even with this evidence, we recognize that the qualitative decision to be made is extremely difficult. Absent such evidence, though, a rational decision borders on the impossible.

3. The Bottom Twenty Schools. Finally, the twenty or so schools that cannot reasonably claim membership in the top fifty present special probleins. At least some of these schools are admitting a very large percentage of those who apply, including applicants with a limited demonstrated capacity to complete law school under reasonable grading standards. At least some of the schools may be in violation of $A B A$ Standards ${ }^{42}$ and AALS Bylaws. ${ }^{43}$ Several schools have involuntarily re-

41. Forty-six states and the District of Columbia require the MBE. Only Indiana, Iowa, Louisiana, and Washington do not. See BAR/BRI DIGEST (1987).

42. Schools that admit virtually all who apply are almost certainly in violation of Standard 501, which provides: "The admission policies of the law school shall be consistent with the objective of its educational program and the resources available for implementing those objectives. The school may not admit applicants who do not appear capable of satisfactorily completing that program." STANDARDS FOR APPROVAl OF LAW Schools Standard 501 (1986) (emphasis added). Standard 209(a) addresses the problem of open admissions as follows:

If tuition is a substantial source of the law school's income, the school is faced with a potential conflict of interest whenever the exercise of sound judgment in the application of admission policies or academic standards and retention policies might reduce enrollment 
duced enrollment because fewer persons have applied than they are prepared to admit, or because a large number of the applicants they do admit are opting to attend otlier schools. If reasonable academic standards are apphied, the second- and third-year classes at some of the schools will be so small that the schools will be unable to fund themselves. In the long run, the process of lowering grading standards is selfdefeating; the failure to apply rigorous grading standards will be reflected in poor bar examination results and a furtler decline in demand as prospective apphicants learn the facts. If a reduction in enrollment is not an available option, the only solution nay be to withdraw ABA approval or AALS meinbership, a drastic step that will require substantial courage.

\section{B. The Future-Some Predictions.}

Because there are so many variables, it is difficult to predict witl any degree of certainty low large the law school applicant pool will be over the next few years. The Astin data may provide a clue, albeit a somewhat uncertain one. Our discussion of the future is presented witl full awareness that the one consistent pattern that emerges from enrollment projections in higher education is that they are almost always wrong.

1. The Astin Data. The Astin data show that there is a fairly strong correlation between the attitudes of freshmen about legal education and the size of the law scliool applicant pool when the freslimen have become semors. Thus, the modest 1982 increase in the number of freshmen (botl men and women) who expected to earn a J.D. degree is consistent with the shight upturn in the law school applicant pool during the 1985-86 admission year. Figure IX illustrates the relationship between the expressed interest of undergraduate freshmen and the law school applicant pool three years later. (The 1982-83 freshman who stayed in scliool and applied to law scliool during his or lier senior year is

below the level necessary to support its program. The law school shall not permit financial considerations detrimentally to affect those policies and their administration.

Id. Standard 209(a). In interpreting Standards 209(a) and 501, the Council of the Section of Legal Education and Admissions to the Bar has said: "A law school which denies almost no one admission for academic reasons and which is experiencing consistently declining average LSAT scores, combined with low GPA's, for admitted students and which has operating deficits and heavy dependence on tuition income, does not comply with Standards 209(a) and 501." Id. I209.

43. Bylaw 6-2a provides:

A member school shall employ admission standards designed to admit only those applicants who are adequately equipped for the study of law. A member school should determine whether an applicant is adequately equipped for the study of law upon the basis of the undergraduate academic record, an admission test score, training, experience, and other indicia of aptitude for the study of law.

Association of AMERICAN LAw SchOOLs Bylaw 6-2a (1986). 


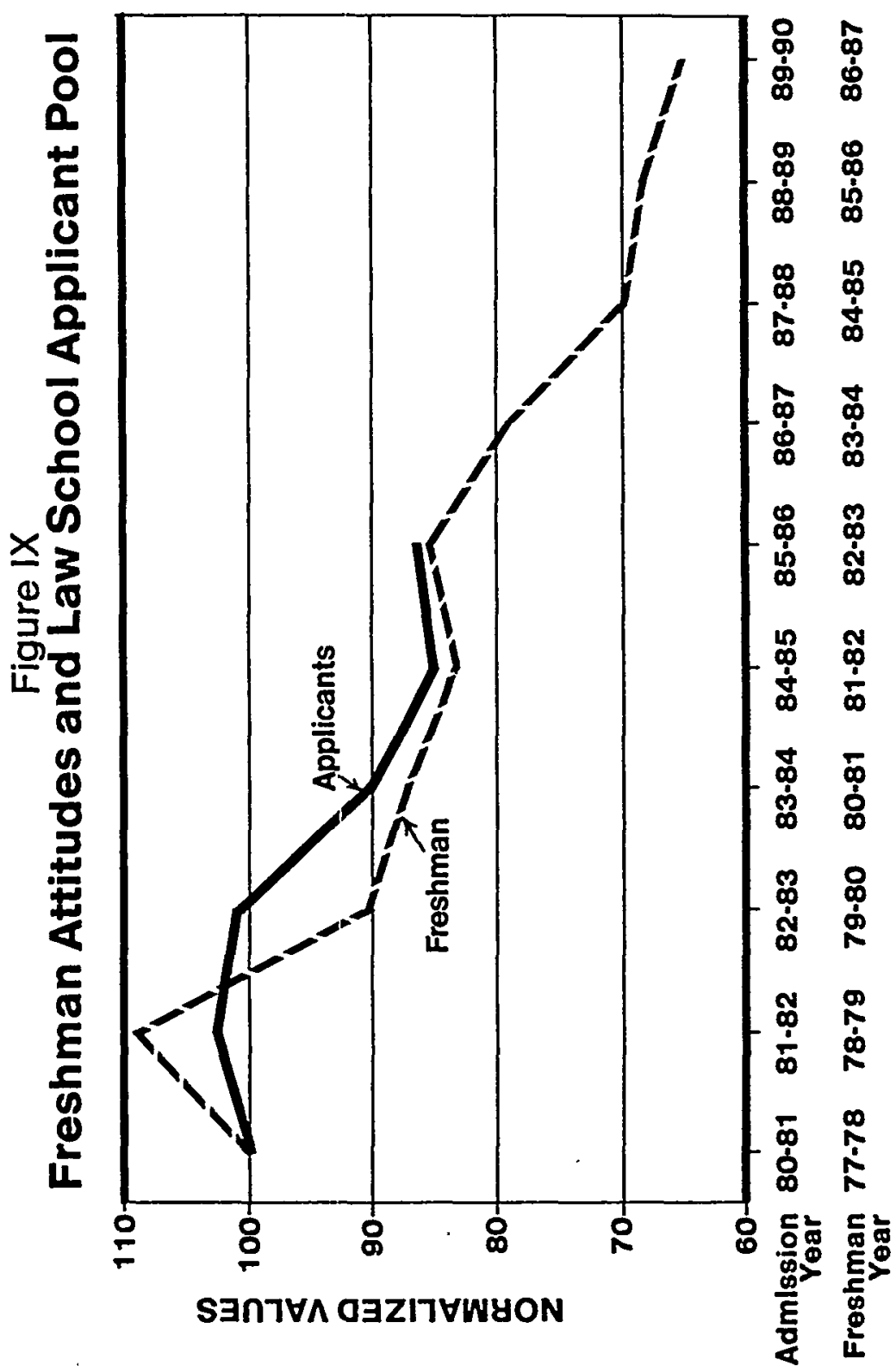


hikely to have applied in the fall of 1985 for admission in 1986.) The correlation is quite striking and indicates that the law school applicant pool will fall in each of the next four years. ${ }^{44}$

We would be much more comfortable using the Astin data for predictive purposes if there were a direct correlation between the percentage of freshmen who expected to earn J.D. degrees and the number of seniors who apply to law schools three years later. With a direct correlation, the number of senior applicants would have risen in the 1985-86 admission year to reflect the 1982 increase in freshman interest. The fact is, however, that the number of senior applicants fell somewhat in 1985-86. Whatever correlation is present relates to the size of the overall pool three years later and not to the number of college seniors applying to law school.

One might conclude that the 1986 correlation was siniply fortuitous. Figure IX, however, demonstrates a high correlation between freshinan attitudes toward legal education froin 1975 to 1982 and the size of the law school applicant pool three years later. The correlation is particularly high for the 1984-85 and 1985-86 adnission years. We have no satisfactory explanation for the correlation over the past several years and can only point out that historically the figures mesh. If the applicant pool continues to track the Astin data, the pool inay shrink as much as $10 \%$ to $15 \%$ over the next three years.

2. Senior Applicants and Others. The 1986 increase in the number of applicants who earned degrees one or more years before applying to law school inore than offset the decrease in the nuniber of undergraduate seniors who applied. The nuinber of applicants who were out of school one or more years may continue to increase, preventing a significant decline in the size of the applicant pool over the next few years. We have no way of knowing, however, why there has been a steady decline in the number of applications from undergraduate seniors or whether the decline will continue. We do not know why the 1985-86 admission year saw a reversal of the four-year downward trend of applicants who were out of school for one or more years before applying to law school. A decrease in the availability of jobs for graduating seniors in 1986-87 might contribute very directly to an increase in the size of the law school applicant pool.45 More young college graduates may seek a

44. A survey of 1500 members of the Harvard College class of 1986 reveals that the percentage of students planning to study law had fallen to $10 \%$ from a high of $19 \%$ in 1981 . More Harvard Graduates Pick Academic Careers, Chronicle Higher Educ., Dec. 17, 1986, at 2, col. 5.

45. One source reports that employers are expected to hire about the same number of college graduates in 1987 as they did in 1986. Greene, Job Outlook for 1987's Graduating Seniors: Level Hiring, Lagging Pay, and Drug Tests, Chronicle Higher Educ., Jan. 7, 1987, at 33, col. 2. 
legal education if other large companies follow General Motors and AT\&T in making large staff reductions. ${ }^{46} \mathrm{~A}$ general downturn in the economy might have the same effect, because relatively young college graduates are likely to be among the first to lose their jobs. The problem is exacerbated somewhat by the fact that the number of undergraduate degrees awarded is expected to continue to decrease at least until 1994.

If the percentage of senior applicants in the law school applicant pool continues to decrease at the same rate it did between 1985 and 1986, i.e., $0.05 \%$, the size of the law school applicant pool will decrease over the next several years (Table 9) unless the other applicants (the $60 \%$ who apply one or more years after earning undergraduate degrees) take up the

Table 9

Projection of \% of Graduating Semors Likely to Apply to Law School Prior to Earning Their Undergraduate Degrees: 1987-1993

\begin{tabular}{|ccccc|}
\hline Year & $\begin{array}{c}\text { Undergraduate } \\
\text { Degrees Awarded }\end{array}$ & $\begin{array}{c}\text { \% of } \\
\text { Senior Pool }\end{array}$ & $\begin{array}{c}\text { Senior Applicants } \\
\text { to Law School }\end{array}$ & $\begin{array}{c}\text { 1ndex (1982 } \\
\text { as Base } \\
(30,528))\end{array}$ \\
1987 & 935,000 & 2.53 & 23,655 & 77 \\
1988 & 927,000 & 2.48 & 22,990 & 75 \\
1989 & 927,000 & 2.43 & 22,526 & 74 \\
1990 & 927,000 & 2.38 & 22,063 & 72 \\
1991 & 922,000 & 2.33 & 21,483 & 70 \\
1992 & 915,000 & 2.28 & 20,862 & 68 \\
1993 & 900,000 & 2.23 & 20,070 & 66 \\
\hline
\end{tabular}

slack. If the latter group declines, even at a modest rate, as it has every year since 1982 with the exception of 1986, the size of the apphicant pool will be reduced more substantially.

By combining the trend $\mathrm{m}$ the number of senior applicants with the trend in the number of applicants who apply one or more years after earning an undergraduate degree (Table 4), we can speculate about what may happen in the near future. Because we are dealing with very large numbers of graduates (more than 900,000) and comparatively small numbers of law school applicants $(60,000)$, small shifts in the percentage of college graduates interested in law school can change the size of the law school applicant pool substantially.

46. General Motors planned temporary lay-offs of 24,200 employees. See Holusha, G.M.'s Production Cuts Leave Analysts Wary. N.Y. Times, Dec. 22, 1986, at D1, col. 1. AT\&T also planned to reduce its work force by $27,400,10,900$ of whom were to be persons holding management positions. See Feder, AT\&T Will Cut 27,400 Jobs, N.Y. Tïmes, Dec. 19, 1986, at D1, col. 6. 
There were 795 more applicants in the 1986 pool than in the 1985 pool. The 964 drop in graduating senior applicants was offset by the 1759 increase in applicants who apphed one or more years after having earned their undergraduate degrees. If the 1986 increase of $4.9 \%$ in the number of apphicants who earned degrees one or more years before applying to law schools represents more than a one-year reversal of the trend, the law school applicant pool will increase somewhat over the next few years even if the number of college seniors who apply continues to decrease at the same rate as in 1986 . Although we obviously cannot predict whether one scenario is more likely than any other, our mstinct is that we will see a modest decrease in the law school apphicant pool over the next three or four years. In essence, we tend to take the Astin data somewhat more seriously than the other data, but we lack the confidence to ignore the 1986 upturn.

\section{CONCLUSION}

For most law schools, the declining interest in legal education over the last five years would have been of relatively httle importance had the academic credentials of the apphcants not decreased at a faster rate. Law schools effectively dealt with a similar drastic decrease in enrollment following the boon that occurred after World War II.47 However, unlike the boom that followed World War II, the surge of interest in legal education that occurred in the 1970's and early 1980's (caused by the increased number of women applicants) ${ }^{48}$ gave rise to the creation of several new law schools ${ }^{49}$ and the expansion of both plant and staff at existing law schools. ${ }^{50}$ Thus, today the declining interest in legal education coupled with an even faster decline in the academic credentials of

47. See Vernon, Anatomy of Legal Education (Report of the Tunks Committee): The Way We Were and the Way We Are, 60 WASH. L. REv. 571, 574 (1985).

48. See Vernon \& Zimmer, supra note 3, at 270.

49. From 1972 to 1985 , there were 25 new law schools added to the ABA's list of approved schools, not counting Antioch and Oral Roberts, which were removed from the list in 1986. Six of the newly approved schools were state-supported and 19 were private. In the fall of 1985, the 25 newly approved schools had total enrollments of 14,199 , with the state-supported schools enrolling 2456 of that total.

The 25 schools approved in 1972 or thereafter had a total entering classes of 4994 in the Fall of 1985 , or $12.4 \%$ of the national total.

50. The bulk of the expansion in law school enrollment resulted from the opening of new law schools rather than the expansion of existing law schools. Although many of the 147 schools on the ABA's list of approved schools in 1972 subsequently expanded the size of their faculties, the entering classes at those schools were only 3\% larger in 1985 than in 1972, rising from 34,402 in 1972 to 35,479 in 1985. During the same period, the full-time faculty at the 147 schools rose from 3389 to 4286. See 1985 REPORT, supra, note 7, at 65; 1972 REPORT, supra note 7, at 40. 
applicants presents serious problems for law schools, accrediting associations, the legal community, and the public.

While it is easy to argue that a $25 \%$ reduction in the number of law students is the only way to restore and maintain the quality of legal education at the 1982 level, reducing enrollment can be a painful process. Furthermore, it is nonsensical to think about size reduction in national terms or as an across-the-board process in which each of the 173 approved schools reduces enrollment by $25 \%$. It inakes neither educational nor fiscal sense for the very selective schools to reduce their size when the academic credentials of their student bodies remain at the same high level. In fact, it makes little fiscal or educational sense for any school to reduce its size if the academic abilities of its student body are sufficient to permit the faculty to teach at an in-depth level and if the grading standards applied weed out students who fail to demonstrate competence. The two "ifs" in the previous sentence are the factors on which each school and the national associations should focus as they attempt to protect the public from incompetent lawyers.

In thinking about the problem, one should remember that the qualitative norms and expectations in legal education increased dramatically from the early 1970's to the early 1980's. The breadth of the educational experience expanded and clinical education was established. The student-faculty ratio improved dramatically. The qualitative improvements have been expensive, particularly the one-on-one supervision required for good clinical education. The qualitative inprovements in academic programs were accompanied by a parallel improvement in the academic credentials presented by applicants. Starting in 1982 or 1983, however, the credentials started to fall and, as of 1986 , they seemed to be roughly equivalent to the credential mix of the early 1970's. ${ }^{51}$

As the ABA and the AALS attempt to ensure minimum qualitative standards for the educational programs of the late 1980's and early 1990 's, they must decide whether the gains made by legal education are sufficiently important to warrant the withdrawal of approval or membership from schools that cannot afford broad-gauged educational programs and well-supervised clinics. In the same vein, they must decide whether some schools are reaching so far down in the applicant pool as to violate the Standards of the ABA and the Bylaws of the AALS. ${ }^{52}$ The interest

51. Because of the change in LSAT scoring and possible shifts in undergraduate grading patterns, only a rough comparison can be made.

52. The language of the provisions set forth supra notes $42-43$ concerning minimum academic credentials of law students is sufficiently general to raise serious questions of adequate notice to schools whose accreditation or membership is revoked for a violation. The associations should give thought to redrafting these provisions if they are seriously considering applying them. 
of the public must be the dominant consideration. Part of the indiscriminate enrollment issue will require the associations to ensure that students are not misled about the hikelihood of their graduation and the likelihood that they have the capacity to practice law competently. The ABA and the AALS face formidable tasks. 